\title{
Isotopic signals in an agricultural watershed suggest denitrification is locally intensive in riparian areas but extensive in upland soils
}

\author{
W. A. Sigler $\mathbb{B} \cdot$ S. A. Ewing $\mathbb{D}$ - \\ S. D. Wankel ${ }^{\circledR}$ - C. A. Jones $®$ - S. Leuthold • \\ E. N. J. Brookshire ${ }^{\circledR} \cdot$ R. A. Payn ${ }^{(1)}$
}

Received: 19 March 2021 / Accepted: 23 January 2022 / Published online: 11 February 2022

(C) The Author(s) 2022

\begin{abstract}
Nitrogen loss from cultivated soils threatens the economic and environmental sustainability of agriculture. Nitrate $\left(\mathrm{NO}_{3}{ }^{-}\right)$derived from nitrification of nitrogen fertilizer and ammonified soil organic nitrogen may be lost from soils via denitrification, producing dinitrogen gas $\left(\mathrm{N}_{2}\right)$ or the greenhouse gas nitrous oxide $\left(\mathrm{N}_{2} \mathrm{O}\right)$. Nitrate that accumulates in soils is also subject to leaching loss, which can degrade water quality and make $\mathrm{NO}_{3}{ }^{-}$available
\end{abstract}

Responsible editor: Ishi Buffam.

Supplementary Information The online version contains supplementary material available at https://doi. org/10.1007/s10533-022-00898-9.

W. A. Sigler $(\bowtie) \cdot$ S. A. Ewing · C. A. Jones ·

S. Leuthold · E. N. J. Brookshire · R. A. Payn

Land Resources and Environmental Sciences, Montana

State University Bozeman, Leon Johnson Hall Room 334,

Bozeman, MT 59717, USA

e-mail: asigler@montana.edu

W. A. Sigler · C. A. Jones

Montana State University Extension, Montana State

University, Bozeman, MT 59717, USA

S. D. Wankel

Department of Marine Chemistry and Geochemistry, Woods Hole Oceanographic Institution, Woods Hole, MA 02540, USA

S. Leuthold

Soil and Crop Sciences Department, Colorado State

University, Fort Collins, CO 80524, USA for downstream denitrification. Here we use patterns in the isotopic composition of $\mathrm{NO}_{3}{ }^{-}$observed from 2012 to 2017 to characterize $\mathrm{N}$ loss to denitrification within soils, groundwater, and stream riparian corridors of a non-irrigated agroecosystem in the northern Great Plains (Judith River Watershed, Montana, USA). We find evidence for denitrification across these domains, expressed as a positive linear relationship between $\delta^{15} \mathrm{~N}$ and $\delta^{18} \mathrm{O}$ values of $\mathrm{NO}_{3}{ }^{-}$, as well as increasing $\delta^{15} \mathrm{~N}$ values with decreasing $\mathrm{NO}_{3}{ }^{-}$ concentration. In soils, isotopic evidence of denitrification was present during fallow periods (no crop growing), despite net accumulation of $\mathrm{NO}_{3}{ }^{-}$from the nitrification of ammonified soil organic nitrogen. We combine previous results for soil $\mathrm{NO}_{3}{ }^{-}$mass balance with $\delta^{15} \mathrm{~N}$ mass balance to estimate denitrification rates in soil relative to groundwater and streams. Substantial denitrification from soils during fallow periods may be masked by nitrification of ammonified soil organic nitrogen, representing a hidden loss of soil organic nitrogen and an under-quantified flux of $\mathrm{N}$ to the atmosphere. Globally, cultivated land spends ca. $50 \%$ of time in a fallow condition; denitrification in fallow soils may be an overlooked but globally significant source of agricultural $\mathrm{N}_{2} \mathrm{O}$ emissions, which must be reduced along-side other emissions to meet Paris Agreement goals for slowing global temperature increase.

Keywords Nitrogen - Agriculture - Soil · Water · Leaching $\cdot$ Fallow 


\section{Introduction}

Over the last ca. 150 years, anthropogenic fixation of dinitrogen $\left(\mathrm{N}_{2}\right)$ gas into reactive $\mathrm{N}\left(\mathrm{N}_{\mathrm{r}}\right)$ has increased by an order of magnitude (annual total mass estimates of $15 \mathrm{Tg} \mathrm{N}$ in 1860 to $165 \mathrm{Tg} \mathrm{N}$ in 2000; Galloway et al. 2003). Approximately 85\% of $\mathrm{N}_{\mathrm{r}}$ fixed by humans is used to produce fertilizer for crop production. However, global-scale fertilization has also resulted in a cascade of disruptive side effects on planetary systems (Galloway et al. 2003; Erisman et al. 2008; Rockstrom et al. 2009). Nitrogen fertilizer is typically applied to agricultural soils in a reduced form such as ammonium or urea, which is subject to biogeochemical transformations and loss from soil that compromise the goal of $\mathrm{N}_{\mathrm{r}}$ delivery to plants. The generally aerobic conditions common in cultivated soils favor oxidation of reduced $\mathrm{N}$ compounds to nitrate $\left(\mathrm{NO}_{3}{ }^{-}\right)$, which is susceptible to export via leaching due to its high solubility and limited potential to sorb to soils (Sparks 2003). Nitrate often dominates the $\mathrm{N}$ transported through groundwater and surface water flows and is a primary agent of water quality degradation in aquifers, river networks, and estuaries (Vitousek et al. 1997; Caraco and Cole 1999; Goolsby et al. 1999; Smith 2003; Puckett et al. 2011; Tesoriero et al. 2013). While the need to reduce $\mathrm{NO}_{3}{ }^{-}$losses is well recognized, human activity in many systems has resulted in large surplus $\mathrm{N}$ storage in soils (Sebilo, et al. 2013; Van Meter et al. 2016), vadose zones (Ascott et al. 2017), and groundwater (Vautier et al. 2021), suggesting water quality response will likely lag behind any management to reduce $\mathrm{N}$ inputs (Ehrhardt et al. 2019).

Microbial denitrification is the primary means by which $\mathrm{N}_{\mathrm{r}}$ is returned to the non-reactive atmospheric $\mathrm{N}_{2}$ pool, but this process can also produce the greenhouse gas $\mathrm{N}_{2} \mathrm{O}$ (ratio for major river basins in France $=0.015 \pm 0.05$; Billen et al. 2020). Soils and freshwater environments contribute about equally to the $40 \%$ of global denitrification that is non-oceanic (groundwater, lakes, rivers; Seitzinger et al. 2006). Excluding surface water, soils have been estimated to host ca. $70 \%$ of total terrestrial denitrification $(96 \mathrm{Tg}$ $\mathrm{N} / \mathrm{y}$ ), underscoring the importance of their role in global denitrification (Bouwman et al. 2013). Perhaps less understood is the role soils play in the fraction of terrestrial denitrification hosted by groundwater $(25 \%)$ and riparian areas (5\%), due to leaching losses from soils that deliver $\mathrm{NO}_{3}{ }^{-}$to those downstream domains (Goolsby et al. 1999; Bouwman et al. 2013). The growing importance of this central role of soils is evident from a $70 \%$ increase in the global soil $\mathrm{N}$ budget surplus (inputs minus withdrawal by plants) over the last century (118-202 Tg/y from 1900 to 2000), with parallel increases in terrestrial denitrification $(52-96 \mathrm{Tg} / \mathrm{y})$ equating to ca. $45 \%$ of the surplus (Bouwman et al. 2013).

Though the general controls on denitrification in soils are well understood $\left(\mathrm{NO}_{3}{ }^{-}\right.$supply, anoxia and organic carbon availability; Del Grosso et al. 2000), specific predictions of denitrification rates across space and time are hampered by a poor understanding of the influence of heterogeneity within the soil environment (Firestone and Davidson 1989; Schlüter et al. 2019). Soils commonly host nitrifying conditions adjacent in space and/or time to denitrifying conditions, and accordingly can support high denitrification rates by providing an abundant supply of $\mathrm{NO}_{3}{ }^{-}$and labile $\mathrm{C}$ to denitrifying bacterial communities. An abundance of dissolved oxygen (DO) as a more energetically favorable electron acceptor for bacterial metabolism limits denitrification in soil, and DO concentrations are generally lower in soils with higher water content (Smith et al. 1997), though oxygen limited zones may occur within structural units even in well drained soils (Ewing et al. 2006). When not suppressed by toxic conditions, the availability of electron donors and $\mathrm{NO}_{3}{ }^{-}$also limit rates of denitrification (Firestone and Davidson 1989). The abundance of organic carbon is the most common limitation on electron donor availability, though the abundance of reduced $\mathrm{Fe}$ and $\mathrm{S}$ chemical species may be important in systems or zones depleted of labile organic matter (Kolbe et al. 2019; Bochet et al. 2020). High spatial and temporal variability in DO, organic carbon, and $\mathrm{NO}_{3}{ }^{-}$hinder direct quantification of denitrification rates, along with difficulty in measuring $\mathrm{N}_{2}$ production due to the high background concentration of $\mathrm{N}_{2}$ in the environment (Groffman et al. 2006).

Overcoming these methodological difficulties is perhaps most pressing for the world's croplands, which generate the vast majority of anthropogenic $\mathrm{N}_{2} \mathrm{O}$ emissions (Tian et al. 2019). Cropland management to augment $\mathrm{N}_{r}$ (via fertilization) and water (via irrigation and/or crop rotation) availability for crops, can have the unintended consequence of increased leaching and denitrification. Numerous studies have 
examined denitrification in irrigated agricultural soils, where anthropogenic controls on water-mediated rates of denitrification are directly evident (Rolston et al. 1982; DeKlein and VanLogtestijn 1996; Scheer et al. 2008; Liu et al. 2011). Studies of the controls on denitrification in non-irrigated systems are much less common, despite the fact that non-irrigated agriculture represents about $80 \%$ of global cultivated land area (Siebert et al. 2005; Foley et al. 2011) and has equal or greater challenges with $\mathrm{N}_{r}$ use efficiency. Furthermore, research in the context of non-irrigated agriculture has primarily been conducted in relatively wet climates $(>0.5 \mathrm{~m}$ annual precipitation; Becker et al. 2007; Sander et al. 2014; Wells et al. 2014; Vazquez et al. 2019), with semi-arid landscapes receiving less attention (Barton et al. 2013), despite $50 \%$ of global cultivated land occurring in semi-arid regions (Safriel and Adeel 2005).

Just as water is applied to augment precipitation in irrigated systems, summer fallow periods (suppression of plant growth with herbicides or tillage throughout a summer growing season) are commonly included in dryland crop rotations to store water for the subsequent crop (Probert et al. 1998; Nielsen et al. 2005). Fallow periods can be limited to an annual non-growing season, can include the summer growing season (summer fallow), or extend for multiple years and collectively represent ca. $50 \%$ of a given year across cultivated land area globally (Siebert et al. 2010). There is a growing appreciation for the role of non-growing season fallow periods in overall denitrification losses from cultivated soils (Shang et al. 2020), but relatively few studies address denitrification rates during summer fallow periods (Vazquez et al. 2019). Furthermore, summer fallow periods and associated increases in soil water content have been linked to higher $\mathrm{NO}_{3}{ }^{-}$leaching losses (Campbell et al. 2006; John et al. 2017; Sigler et al. 2020), but few studies (Davis et al. 2019) have explored the extent to which these periods of higher soil water content also influence denitrification in soils and downgradient aquifers or riparian corridors.

High leaching and denitrification losses are symptomatic of widespread $\mathrm{N}_{r}$ use inefficiencies in agricultural production (Galloway et al. 2003) but may be particularly severe where and when summer fallowing is practiced (Sigler et al. 2018). These inefficiencies compromise tenets of agroecosystem sustainability, which seek to balance crop production needs with protection of soil and water resources, while mitigating anthropogenic $\mathrm{N}$ loading that leads to $\mathrm{N}_{2} \mathrm{O}$ related climate forcing (Committee on Twenty-First Century Systems Agriculture 2010). Minimizing environmental harms resulting from inefficient use of $\mathrm{N}_{r}$ in agricultural production requires detailed knowledge of the interactions between agricultural management practices such as fallowing, and the drivers of denitrification.

The objective of this study is to understand the role of denitrification as a pathway of $\mathrm{N}_{r}$ loss across hydrologically connected soils, groundwater, and stream corridors in non-irrigated agricultural systems. Our strategy to achieve this objective was to explore patterns in dissolved organic carbon (DOC), DO, and $\mathrm{NO}_{3}{ }^{-}$concentrations along with isotopic composition of water and $\mathrm{NO}_{3}{ }^{-}$within a non-irrigated, semiarid agroecosystem in central Montana, USA. The isotopic composition of $\mathrm{N}$ and $\mathrm{O}$ in $\mathrm{NO}_{3}{ }^{-}$can help to discern the influence of denitrification, due to the large isotopic fractionation that microbial metabolism imprints on the residual $\mathrm{NO}_{3}{ }^{-}$pool (Groffman et al. 2006). We therefore use patterns in $\delta^{15} \mathrm{~N}$ and $\delta^{18} \mathrm{O}$ values in $\mathrm{NO}_{3}{ }^{-}$across soil water, groundwater, and stream water to examine rates and environmental drivers of $\mathrm{N}_{\mathrm{r}}$ loss to denitrification across these domains. We hypothesize that in soils, DOC supply, consumption of $\mathrm{DO}$, and production of $\mathrm{NO}_{3}{ }^{-}$support substantial denitrification during summer fallow periods when higher soil water content is sustained within this semi-arid environment. More broadly, we use patterns in water and $\mathrm{NO}_{3}{ }^{-}$isotopes to examine hypotheses (Sigler et al. 2018) that denitrification is minimal in groundwater at this site due to high DO and short residence times (Tesoriero and Puckett 2011) but substantial in riparian corridors (Vidon and Hill 2006) where groundwater travels through saturated, carbon-rich, riparian soils before entering streams.

\section{Methods}

Study area

The study area is in central Montana within the Judith River Watershed (HUC 10040103; Fig. 1). The Judith River is a headwater tributary to the Missouri River, and streams and shallow terrace aquifers in the 


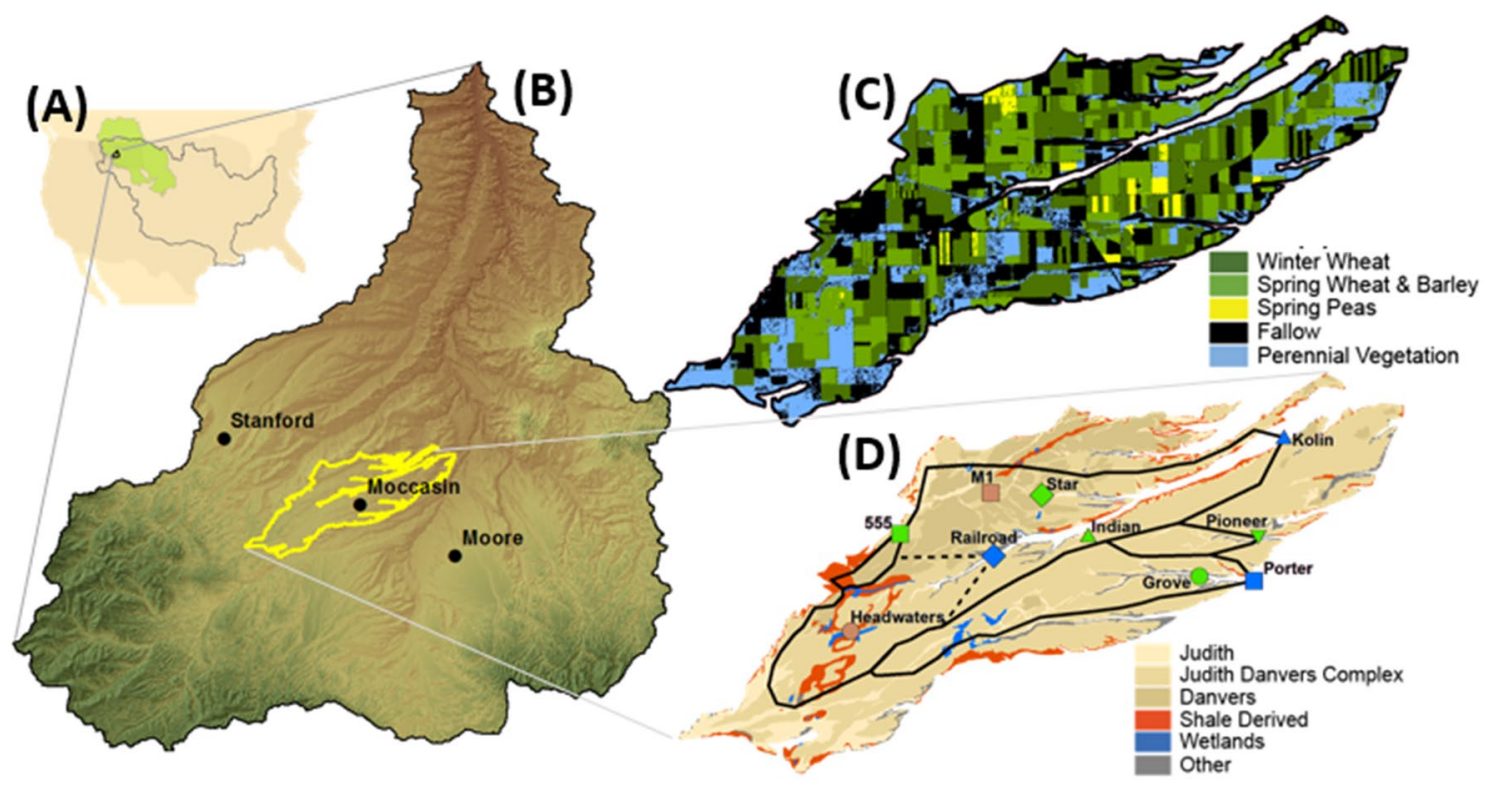

Fig. 1 Study area. Location and character of the Judith River Watershed (JRW) and Moccasin terrace in the context of: A the location of the study area within the United States, the northern Great Plains (green shaded area), and the Mississippi Atchafalaya River Basin (gray outline); B the locations of the Moccasin terrace and towns nearest to the study fields where lysimeters and rain water samplers were installed; $\mathbf{C}$ land use on the Moccasin terrace for the 2014 growing season (USDA 2014); and D soil series, catchments (black outlines), and stream sample sites (blue symbols), non-riparian groundwater sample sites (brown symbols), and riparian groundwater sample sites (green symbols) on the Moccasin terrace. Symbol shapes match those of Sigler et al. (2018)

estimate soil organic nitrogen (SON) is $3,100 \mathrm{~kg} \mathrm{~N} /$ ha in the top $15 \mathrm{~cm}$ (Supplemental Information). Unconfined aquifers are perched on shale and generally shallow (1-10 m below ground surface), with a saturated thickness of 2-6 $\mathrm{m}$ and mean groundwater residence times ranging from $<1$ to 20 years (Sigler et al. 2018). Here we focus on the aquifer within the Moccasin strath terrace (Fig. 1). Topography, stratigraphy, and water chemistry suggest that groundwater recharge on the terrace occurs exclusively via infiltration of precipitation through local soils, and $72 \%$ of the terrace area is used for cultivation of annual crops (Sigler et al. 2018). Common crop rotations in the area result in approximately $25 \%$ of the terrace being in summer fallow in a year (Sigler et al. 2018) and an overall annual fallow fraction of greater than 0.6 for the annually cultivated portion of the terrace (Sigler et al. 2020). The shallow aquifers and streams emerging from them are well-suited to research on variation in the controls on denitrification because the terrace has well-defined hydrologic boundaries, and soils across the terrace are of varying thicknesses and 
textures that dictate a range of water storage and biogeochemical conditions (Sigler et al. 2018, 2020).

Sampling and analysis

We infer fate and transport of $\mathrm{N}_{\mathrm{r}}$ through components of the agroecosystem from the chemical and isotopic composition of soil water, groundwater, and stream water sampled across space and time between 2012 and 2017. Soil solution chemistry was characterized in samples from tension lysimeters (PTFE/silica; Prenart Equipment; Frederiksberg, Denmark) installed in two non-irrigated fields operated by cooperating farmers (Field B near Moccasin, and Field C near Moore, Fig. 1). Lysimeters were installed near the bottom of the fine textured soil horizons, with nine in soils with relatively thin fine-textured zones $(40-80 \mathrm{~cm}$; shallow) and nine in soils with relatively thick fine-textured zones (80-120 cm; deep). Lysimeters were visited approximately every two weeks during periods with sufficient soil water to produce samples between 2013 and 2016. Groundwater and surface water sampling between 2012 and 2017 included two wells, five springs, and three stream sites distributed across the Moccasin terrace (Fig. 1; Sigler et al. 2018). The terrace aquifer, which is isolated from riparian influence due to stream incision, was assessed using upland wells. Springs are located both adjacent to and within riparian areas and represent a range of influence from the riparian environment, determined by geomorphic context at the spring orifice. Dissolved oxygen was measured in-situ with a multiparameter water quality meter using a pump and a flow-through cell (YSI 556; YSI Incorporated; Yellow Springs, Ohio, USA). Dissolved organic carbon was determined using a V-TOC CSH Total Carbon Auto-Analyzer (Shimadzu Corporation). Nitrate concentrations were analyzed by ion chromatography (Dionex, ICS-2100, AS18 column) and/or by cadmium reduction and colorimetry (Lachat, QuickChem 8,500; Seal, QuAAtro). Major ions in soil water, groundwater, and stream samples for the four-year sample period (2013-2016) were characterized previously (Sigler et al. 2018). Isotopic composition of $\mathrm{NO}_{3}^{-}\left(\delta^{15} \mathrm{~N}, \delta^{18} \mathrm{O}\right)$ was analyzed in groundwater and stream samples, with a minimum of four samples for each site selected to represent a range of seasonal and flow conditions. Isotopic composition of $\mathrm{NO}_{3}{ }^{-}$was analyzed in samples from six of the 18 lysimeters, selected to provide equal representation of shallow and deep soil conditions in a field with summer fallow land use in the crop rotation.

Nitrate isotope analyses were conducted at Woods Hole Oceanographic Institution, using the denitrifier method (Sigman et al. 2001; Casciotti et al. 2002). Nitrate $\mathrm{N}$ and $\mathrm{O}$ isotopic values were corrected for drift and linearity, and $\delta$ values were calculated relative to $\mathrm{N}_{2}$ in air $\left(\delta^{15} \mathrm{~N}=\left[\left({ }^{15} \mathrm{~N} /{ }^{14} \mathrm{~N}\right)_{\text {sample }}\right.\right.$ ' $\left.\left.\left({ }^{15} \mathrm{~N} /{ }^{14} \mathrm{~N}\right)_{\text {air }}-1\right] \times 1000\right)$ and to $O$ in Vienna standard mean ocean water (VSMOW; $\delta^{18} \mathrm{O}=\left[\left({ }^{18} \mathrm{O} /{ }^{16} \mathrm{O}\right)_{\text {sample }} /\right.$ $\left.\left.\left({ }^{18} \mathrm{O} /{ }^{16} \mathrm{O}\right)_{\text {VSMOW }}-1\right] \times 1000\right)$ using reference materials USGS 32, USGS 34 and USGS 35. Analytical uncertainty of $\mathrm{NO}_{3}{ }^{-}$isotopic values was calculated from replicate analyses of samples or reference materials with standard deviations (SD) from the means of $0.2 \%$ for $\delta^{15} \mathrm{~N}$ and $0.5 \%$ for $\delta^{18} \mathrm{O}$. When summarizing the range of $\mathrm{NO}_{3}{ }^{-}$isotope values, the $5 \%$ and $95 \%$ quantiles are presented as a $\mathrm{Q}_{5-95}$ range.

Precipitation has potential to influence $\mathrm{NO}_{3}{ }^{-}$isotopic composition via the isotopic ratio of oxygen in water molecules and $\mathrm{NO}_{3}{ }^{-}$dissolved in precipitation waters. More than $85 \%$ of precipitation in the study area occurs in the rain dominated months between April and November (Sigler et al. 2020). Precipitation samples were collected between 2013 and 2016 during these rain-dominated months at three study fields (Fig. 1), using receptacles containing mineral oil to avoid evaporation. A composite sample of snow was collected from the snowpack near Field B and near Field C on 30 March 2014. Water isotope composition of precipitation was characterized to provide context for interpreting $\mathrm{NO}_{3}{ }^{-}$values, with the assumption that it is the primary input of $\delta^{18} \mathrm{O}$ for nitrification after accounting for effects of evaporation (Benettin et al. 2018). Rain and snow samples were analyzed for hydrogen $\left(\delta^{2} \mathrm{H}\right)$ and oxygen $\left(\delta^{18} \mathrm{O}\right)$ isotopic composition in water relative to VSMOW, using off-axis integrated cavity output spectroscopy (Los Gatos Research, Mountain View, CA; Baer et al. 2002). Water isotope analysis was conducted in the Montana State University Environmental Analytical Laboratory, based on reference materials USGS 46, USGS 48, LGR \#2C, and LGR \#3C. A working local groundwater standard included after every fourth sample across eight runs had a standard deviation from the mean of $0.4 \%$ for $\delta^{18} \mathrm{O}$ and $0.6 \%$ or $\delta^{2} \mathrm{H}$. 
Precipitation derived inputs of $\mathrm{NO}_{3}{ }^{-}(1.6 \mathrm{~kg} \mathrm{~N} / \mathrm{ha} /$ yr) were determined to be negligible relative to other inputs (John et al. 2017) and are not addressed further here.

Isotopic signals of denitrification

The $\mathrm{N}$ isotopic composition of nitrogenous compounds is subject to fractionation during transformations within the N cycle (Kendall et al. 2007; Denk et al. 2017). In this work, we focus on fractionation during ammonification, nitrification, and denitrification as the primary processes influencing isotopic composition of dissolved $\mathrm{NO}_{3}{ }^{-}$in our study waters. Within the Moccasin terrace, cultivated soils are the dominant source of $\mathrm{NO}_{3}{ }^{-}$to underlying groundwater and the emergent streams (Sigler et al. 2018). Values for $\delta^{15} \mathrm{~N}$ of $\mathrm{NO}_{3}{ }^{-}\left(\delta^{15} \mathrm{~N}_{\mathrm{NO}_{3}}\right)$ in soil are influenced by isotopic fractionation during nitrification of $\mathrm{N}$ sourced from fertilizer and SON as well as by denitrification that increases $\delta^{15} \mathrm{~N}_{\mathrm{NO}_{3}}$ values in residual $\mathrm{NO}_{3}{ }^{-}$(Granger et al. 2008). The $\delta^{18} \mathrm{O}$ in $\mathrm{NO}_{3}^{-}\left(\delta^{18} \mathrm{O}_{\mathrm{NO}_{3}}\right)$ is influenced by nitrification that imparts the isotopic composition of water and $\mathrm{O}_{2}$ as source oxygen atoms (and associated isotopic effects of incorporation) to the product $\mathrm{NO}_{3}^{-}$, along with an isotopic fractionation by denitrification that increases $\delta^{18} \mathrm{O}_{\mathrm{NO}_{3}}$ values in residual $\mathrm{NO}_{3}{ }^{-}$(Granger et al. 2008; Buchwald and Casciotti 2010; Casciotti et al. 2010; Boshers et al. 2019). The expression of $\delta^{18} \mathrm{O}_{\mathrm{NO}_{3}}$ fractionation via denitrification is also influenced by the $\delta^{18} \mathrm{O}$ value of ambient water due to isotopic exchange with $\mathrm{NO}_{2}^{-}$(Granger and Wankel 2016). We characterize $\mathrm{N}_{r}$ losses to denitrification using observed isotopic values and the $\mathrm{NO}_{3}{ }^{-}$mass balance, applying isotopic effects $(\varepsilon)$ based on literature and observed isotopic values (Table S1; Sigler et al. 2021).

We assessed signals of denitrification by examining relationships between $\mathrm{N}$ and $\mathrm{O}$ isotopic composition and concentration of $\mathrm{NO}_{3}{ }^{-}$(primary evidence), as well as relationships between $\delta^{15} \mathrm{~N}_{\mathrm{NO}_{3}}$ and the concentration of DO and DOC (corroborating evidence). Evidence for denitrification was assessed using the slope, coefficient of determination $\left(\mathrm{R}^{2}\right)$, and probability of falsely identifying a trend ( $p$ value) derived from linear regressions of $\delta^{18} \mathrm{O}_{\mathrm{NO}_{3}}$ versus $\delta^{15} \mathrm{~N}_{\mathrm{NO}_{3}}\left(\delta^{18} \mathrm{O}: \delta^{15} \mathrm{~N}\right)$ and $\delta^{15} \mathrm{~N}_{\mathrm{NO}_{3}}$ versus the natural $\log$ of $\mathrm{NO}_{3}{ }^{-}$concentration $\left(\delta^{35} \mathrm{~N}: \ln \left[\mathrm{NO}_{3}{ }^{-}\right]\right)$. We interpreted a positive $\delta^{18} \mathrm{O}: \delta^{15} \mathrm{~N}$ slope (Granger and
Wankel 2016) and a negative $\delta^{15} \mathrm{~N}: \ln \left[\mathrm{NO}_{3}{ }^{-}\right]$slope as a primary evidence of denitrification assuming fractionation associated with first order kinetics (Kendall and McDonnell 1998). The expected influence of oxygen and DOC concentrations on denitrification were explored as corroborating lines of evidence. A negative slope in the $\delta^{15} \mathrm{~N}_{\mathrm{NO}_{3}}$ versus natural log of DO relationship $\left(\delta^{15} \mathrm{~N}: \ln [\mathrm{DO}]\right)$ was interpreted as corroborating evidence that denitrification was suppressed by oxygen and a positive slope in the $\delta^{15} \mathrm{~N}_{\mathrm{NO}_{3}}$ versus DOC relationship ( $\delta^{15} \mathrm{~N}$ :DOC) was interpreted as corroborating evidence that denitrification was energy limited. Although a measurement of low DO indicates conditions immediately upgradient from the sample site were conducive for denitrification, high DO at a sample site does not preclude the possibility that low DO conditions facilitated denitrification further upgradient, followed by reoxygenation. Similarly, while high DOC at a sample site indicates electron donors may have been present for denitrification locally or immediately upgradient, low DOC does not preclude the possibility that DOC was available upgradient and was removed by respiration and denitrification. Hence, we interpret the DO and DOC relationships independently as separate lines of evidence for denitrification but do not distinguish relative control between these two drivers. Collectively, these regression statistics provide simple metrics for assessing confidence in interpretation of an observed isotopic effect consistent with denitrification.

Estimating fallow soil denitrification rates

Summer fallow land use provides periods of minimal plant uptake that allow a unique opportunity to assess the net effects of nitrification and denitrification on $\mathrm{N}_{r}$ in soil. We use a stochastic Monte Carlo approach to explore the ranges in magnitude of soil denitrification during fallow periods that may be expected to balance the effects of nitrification. For each realization of the Monte Carlo ensemble, a value representing observed soil $\delta^{15} \mathrm{~N}_{\mathrm{NO}_{3}}$ was combined with a random selection of fractionation effects from distributions that span reasonable values observed or implied in the literature (see Table S1 in Supplemental Information; Houlton et al. 2006; Hall et al. 2016; Denk et al. 2017). For the net isotopic effect of ammonification and nitrification of SON, we selected from a uniform 
distribution of values ranging from -3 to $-20 \%$, with negative values favoring the light isotope in the resulting $\mathrm{NO}_{3}{ }^{-}$. For the isotopic effects of denitrification, we selected from a uniform distribution of isotopic effect values ranging from -10 to $-35 \%$, favoring loss of the light isotope and retention of the heavy isotope in the residual $\mathrm{NO}_{3}{ }^{-}$. To represent the range of soil $\delta^{15} \mathrm{~N}_{\mathrm{NO}_{3}}$ values arising from influence of both denitrification and nitrification, we selected from a normal distribution fit to observed lysimeter $\delta^{15} \mathrm{~N}_{\mathrm{NO}_{3}}$ values during fallow periods. We assumed an SON pool with steady-state isotopic composition such that the $\mathrm{NO}_{3}{ }^{-}$derived from SON also has a constant isotopic composition, which is a reasonable assumption given relatively large inventories of SON $(3,100 \mathrm{~kg} \mathrm{~N} / \mathrm{ha}$ in the top $15 \mathrm{~cm}$ of soil; see Supplemental Information).

Total denitrification $\left(N_{\mathrm{den}, T}\right)$ over the period of interest is a function (Eq. 1) of change in $\mathrm{NO}_{3}{ }^{-}$pool size over the period of interest $\left(\Delta N_{T}\right)$ and the ratio of denitrification to nitrification $\left(r_{\mathrm{den}}=\frac{N_{\mathrm{den}}}{N_{\text {nit }}}\right)$. The initial size of the soil $\mathrm{NO}_{3}{ }^{-}$pool is $10 \mathrm{~kg} / \mathrm{h}$, the approximate mean observed in 14 soil pits at the start of the fallow period. The final size of the pool is $45 \mathrm{~kg} \mathrm{~N} / \mathrm{ha}$ based on observations in 13 soil pits at the end of a one-year fallow cycle, representing an $\Delta N_{T}$ value of $35 \mathrm{~kg} / \mathrm{ha} / \mathrm{yr}$ (Sigler et al. 2020). We only included realizations where $r_{\text {den }}$ was less than 1 $\left(N_{\text {den }}<N_{\text {nit }}\right)$ in the Monte Carlo ensemble because an accumulation of $\mathrm{NO}_{3}{ }^{-}$was observed in the soil during the fallow period.

$N_{\mathrm{den}, T}=\frac{\Delta N_{T}}{\left(\frac{1}{r_{\mathrm{den}}}-1\right)}$

The $\delta^{15} \mathrm{~N}_{\mathrm{NO} 3}$ value is a function of $r_{\mathrm{den}}$, the $\delta^{15} \mathrm{~N}$ isotopic effects associated with combined ammonification and nitrification $\left(\varepsilon_{\text {amm+nit }}\right)$ and denitrification $\left(\varepsilon_{\mathrm{den}}\right)$, and the $\delta^{15} \mathrm{~N}$ value for SON $\left(\delta^{15} \mathrm{~N}_{\mathrm{SON}}=+5 \%\right.$; see Table $\mathrm{S} 1$ in Supplemental Information; Mariotti et al. 1981; Houlton et al. 2006; Denk et al. 2017; Ewing et al. 2022). The $\delta^{15} \mathrm{~N}$ value of newly nitrified $\mathrm{NO}_{3}{ }^{-}$entering the soil pool $\left(\delta^{15} N_{\mathrm{NO}_{3} \text {, nit }}\right)$, produced from SON, is a function of $\delta^{15} \mathrm{~N}_{\mathrm{SON}}$ and $\varepsilon$ amm+nit $\left(\delta^{15} N_{\mathrm{NO}_{3}, \text { nit }}=\delta^{15} N_{\mathrm{SON}}+\varepsilon_{\text {amm+nit }}\right)$. Equation 2 describes the net isotopic effect of nitrification and denitrification: $r_{\mathrm{den}} \approx\left(\frac{\delta^{15} N_{\mathrm{NO}_{3}, \text { nit }}-\delta^{15} N_{\mathrm{NO}_{3}}}{\varepsilon_{\mathrm{den}}}\right)$

The steady state approximated by Eq. 2 is parallel to Eq. 14 in Denk et al. $\left(2017 ; r_{\mathrm{den}}=1-f ; \delta^{15} N_{\mathrm{NO}_{3}, \text { nit }}=\delta_{\mathrm{s}, 0}\right.$; $\delta^{15} \mathrm{~N}_{\mathrm{NO}_{3}}=\delta_{\mathrm{S}} ; \varepsilon_{\mathrm{den}}=\varepsilon$ ) for an open system as described by Fry (2006) and is similar to the steady-state approach in Houlton et al. (2006). The steady state results from the assumption that inputs occur at a constant rate with a constant isotopic value (infinite source pool here is $\mathrm{SON}$ ), and the assumption that the isotopic fractionation effects of nitrification (more specifically, ammonification plus nitrification) and denitrification are constant. As observations of isotopic composition of $\mathrm{NO}_{3}{ }^{-}$used in the model are the integration of $\mathrm{N}$ cycling signals transported to lysimeters by the downward flux of soil solution, these rate estimates are attributed to the soil depths of $40-120 \mathrm{~cm}$ that overlie lysimeters. This estimate for the fallow condition provides insight about the possible magnitude of denitrification loss during fallow periods, and the relative magnitude of nitrification and denitrification fluxes.

\section{Results and Discussion}

We observed evidence of denitrification in soils, groundwater, and streams within agricultural regions of the Judith River Watershed, based on positive $\delta^{18} \mathrm{O}: \delta^{15} \mathrm{~N}$ linear relationships and negative $\delta^{15} \mathrm{~N}: \ln \left[\mathrm{NO}_{3}{ }^{-}\right]$linear relationships (Fig. 2, Table 1). Variation in the strength of these relationships across domains provides evidence of competing processes influencing net isotopic dynamics. Generally, we observed patterns consistent with denitrification suppression by oxic conditions (negative $\delta^{15} \mathrm{~N}: \ln [\mathrm{DO}]$ linear relationships) and facilitation by energy availability (positive $\delta^{15} \mathrm{~N}$ :DOC linear relationships; Fig. 3, Table 1). In streams, the presence of a denitrification signal and oxic conditions suggests inmixing of denitrified riparian waters to a domain readily reoxygenated by the atmosphere (Figs. 2, 3).

Nitrate isotopic composition and linkage across domains

The tight cluster of $\mathrm{NO}_{3}{ }^{-}$isotope values for high DO $(>0.18 \mathrm{mM})$ groundwater provides a key reference point for understanding $\mathrm{N}_{\mathrm{r}}$ dynamics in upgradient cultivated soils and downgradient riparian areas and is 


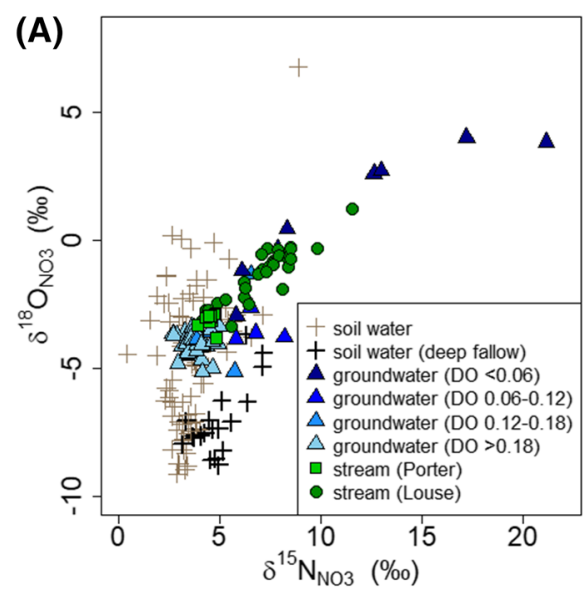

Fig. 2 Nitrate stable isotope results. Comparisons of patterns in isotopic composition and concentration of $\mathrm{NO}_{3}{ }^{-}$dissolved in soil water, groundwater, and stream water across the JRW. Data from groundwater samples are differentiated by DO concentration (shades of blue as denoted in the legend with units

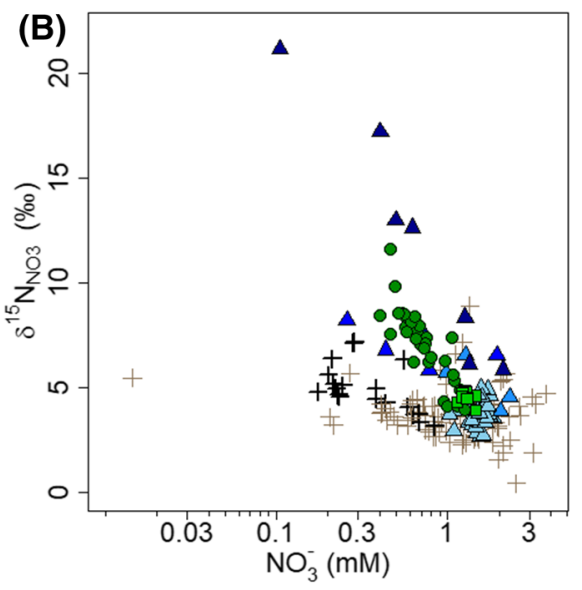

of $\mathrm{mM}$ ). High DO groundwater samples (light blue) represent the terrace aquifer while the lowest DO groundwater samples (dark blue) represent riparian influenced groundwater. $\mathbf{A} \delta^{18} \mathrm{O}$ versus $\delta^{15} \mathrm{~N}_{\text {in } \mathrm{NO}_{3}}^{-}$. B $\delta^{15} \mathrm{~N}_{\text {in } \mathrm{NO}_{3}}^{-}$versus $\mathrm{NO}_{3}{ }^{-}$concentration, note $\mathrm{x}$ axis is $\log$ scaled
Table 1 Summary of denitrification signals in soil water (A), groundwater (B), streams (C), and notable groups of sites (D). Kolin and Railroad are both on Louse Creek. Grove spring is a major source of flow to Porter Creek. Statistics and slopes based on linear relationships. Highlighted cells (gray) are interpreted as "clear" signals where slope (S) has the expected sign and statistical values exceed an arbitrarily designated threshold $\left(\mathrm{R}^{2} \geq 0.5\right.$ and $p$ value $\left.<0.05\right)$

\begin{tabular}{|c|c|c|c|c|c|c|c|c|c|c|c|c|c|}
\hline \multirow{3}{*}{\multicolumn{2}{|c|}{$\begin{array}{c}\text { Sites and Sample } \\
\text { Groups }\end{array}$}} & \multicolumn{6}{|c|}{ Primary Signals } & \multicolumn{6}{|c|}{ Corroborating Signals } \\
\hline & & \multicolumn{3}{|c|}{$\delta^{18} \mathrm{O}: \delta^{15} \mathrm{~N}_{\text {NO3 }}$} & \multicolumn{3}{|c|}{$\delta^{15} \mathrm{~N}: \ln \left[\mathrm{NO}_{3}{ }^{-}\right]$} & \multicolumn{3}{|c|}{$\delta^{15} \mathrm{~N}: \ln [\mathrm{DO}]$} & \multicolumn{3}{|c|}{$\delta^{15} \mathrm{~N}: D O C$} \\
\hline & & $\mathbf{R}^{2}$ & $\mathbf{p}$ & $\mathbf{S}$ & $\mathbf{R}^{2}$ & $\mathbf{p}$ & $\mathbf{S}$ & $\mathbf{R}^{2}$ & $\mathbf{p}$ & $\mathbf{S}$ & $\mathbf{R}^{2}$ & p & $\mathbf{S}$ \\
\hline \multirow{3}{*}{$\mathbf{A}$} & 1 & 0.04 & 0.03 & 0.4 & 0.13 & $<0.05$ & -0.6 & NM & NM & & NM & NM & NM \\
\hline & & 0.09 & 0.06 & & 0.57 & $<0.05$ & -1.4 & NM & NM & & NM & NM & NM \\
\hline & & 0.5 & $<0.05$ & 0.8 & 0.32 & 0.01 & -1.3 & NM & NM & & NM & NM & NM \\
\hline \multirow{8}{*}{ B } & & 0.82 & $<0.05$ & 0.5 & 0.68 & $<0.05$ & -5.2 & 0.75 & $<0.05$ & -2.5 & 0.01 & 0.53 & \\
\hline & Pioneer & 0.88 & $<0.05$ & 0.4 & 0.9 & $<0.05$ & -6.2 & 0.55 & 0.02 & -3.1 & 0.65 & 0.01 & 103.4 \\
\hline & & 0.01 & 0.72 & & 0.72 & $<0.05$ & -2.5 & 0.7 & $<0.05$ & -2.4 & 0.01 & 0.79 & \\
\hline & Headwaters & 1 & $<0.05$ & 0.5 & 0.24 & 0.51 & & 0.47 & 0.32 & & 0.82 & 0.10 & \\
\hline & & 0.02 & 0.66 & & 0.03 & 0.65 & & 0.03 & 0.61 & & 0.01 & 0.78 & \\
\hline & & 0 & 0.96 & & 0.35 & 0.41 & & 0.14 & 0.6 & & 0.78 & 0.12 & \\
\hline & & 0.23 & 0.16 & & 0.02 & 0.68 & & 0.17 & 0.3 & & 0.01 & 0.83 & \\
\hline & & $0.85^{1}$ & 0.08 & & $0.91^{1}$ & $0.05^{1}$ & $1.6^{1}$ & 0.32 & 0.43 & & 0.15 & 0.62 & \\
\hline \multirow{3}{*}{ C } & $\mathbf{P}$ & 0 & 0.94 & & 0.1 & 0.365 & & $0.02^{2}$ & $0.71^{2}$ & & 0.23 & 0.16 & \\
\hline & & 0.73 & $<0.05$ & 0.7 & 0.66 & $<0.05$ & -3 & $0.21^{2}$ & $0.09^{2}$ & & 0.74 & $<0.05$ & 13.8 \\
\hline & & 0.89 & $<0.05$ & 0.5 & 0.82 & $<0.05$ & -5.7 & $0.13^{2}$ & $0.20^{2}$ & & 0.36 & 0.07 & \\
\hline \multirow{2}{*}{ D } & Colin \& Pail & 0.84 & $<0.05$ & 0.6 & 0.74 & $<0.05$ & -4.7 & $0.15^{2}$ & $<0.05^{2}$ & & 0.49 & $<0.05$ & 15.8 \\
\hline & Porter \& Grove & 0.45 & $<0.05$ & 0.6 & 0.73 & $<0.05$ & -2.6 & $0.06^{2}$ & $0.35^{2}$ & & 0.68 & $<0.05$ & 4.8 \\
\hline
\end{tabular}

${ }^{1}$ relationship value exceeds threshold but slope is in the opposite direction as predicted for denitrification

2 stream water column DO not expected to be correlated to denitrification

NM indicates "not measured"

Slope values only reported where significantly different from zero ( $\mathrm{p}$ value $<0.05)$

${ }^{\text {a }}$ Relationship value exceeds threshold but slope is in the opposite direction as predicted for denitrification

${ }^{\mathrm{b}}$ Stream water column DO not expected to be correlated to denitrification

NM indicates "not measured"; Slope values only reported where significantly different from zero $(p$ value $<0.05)$ 


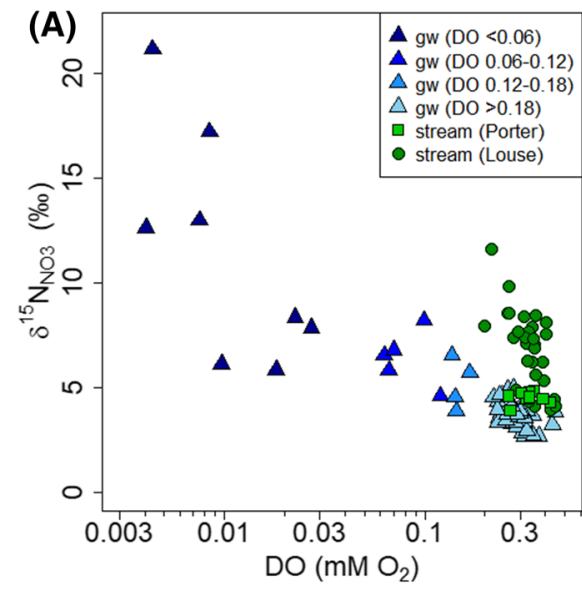

Fig. 3 Nitrate $\delta^{15} \mathrm{~N}$ with dissolved oxygen (DO) and dissolved organic carbon (DOC). Comparisons of patterns in $\delta^{15} \mathrm{~N}$ in $\mathrm{NO}_{3}{ }^{-}$versus DO and DOC dissolved in groundwater and stream water across the JRW. Data from groundwater samples are differentiated by DO concentration (shades of blue as

described here as a foundation for discussion of those dynamics in subsequent sections (Fig. 2, Table S2). Values for $\delta^{15} \mathrm{~N}_{\mathrm{NO}_{3}}, \delta^{18} \mathrm{O}_{\mathrm{NO}_{3}}$, and $\mathrm{NO}_{3}{ }^{-}$concentration in high DO groundwater, sampled in terrace aquifer wells and spring outlets isolated from riparian vegetation, cluster tightly near the center of values for soil, reinforcing findings by Sigler et al. (2018) that chemical composition of the Moccasin terrace aquifer is primarily determined by the chemistry of overlying cultivated soils. The isotopic composition of $\mathrm{NO}_{3}{ }^{-}$apparently carried from soil to groundwater is likely transferred relatively quickly (0-6 years based on tritium-helium analysis) to stream corridors, due to thin $(<6 \mathrm{~m})$ and transmissive terrace aquifers (Sigler et al. 2018). We hypothesize that the shallow, relatively fast-moving groundwater in this terrace system explains why groundwater samples from terrace aquifer wells and spring outlets isolated from riparian vegetation have consistently high DO (Figs. 2 and 3) and that it is riparian sourced DOC that facilitates DO drawdown in the few instances of low DO observed in groundwater sampled at springs. Eight groundwater samples had DO concentrations less than $0.06 \mathrm{mM}$, seven of which came from a single site (Pioneer), where water emerges from an extensive riparian area. The large riparian area upgradient of the Pioneer site stands in contrast to the two well sites and two of the spring sites (Indian and Grove) where water emerges

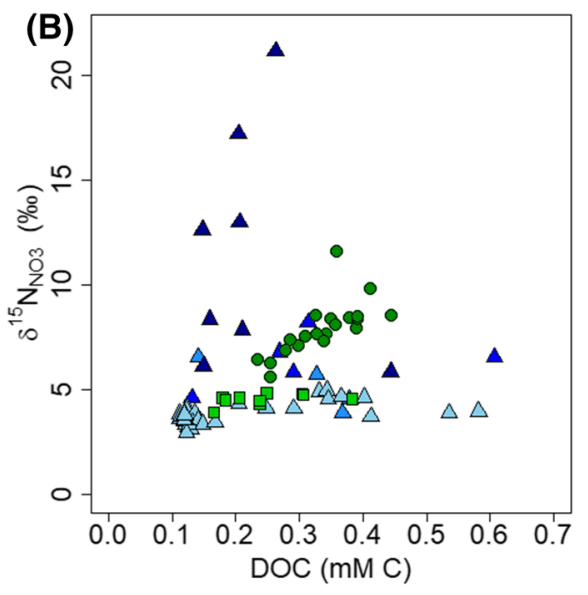

denoted in the legend with units of $\mathrm{mM}$ ). High DO groundwater samples (light blue) represent the terrace aquifer while the lowest DO groundwater samples (dark blue) represent riparian influenced groundwater. A $\delta^{15} \mathrm{~N}$ in $\mathrm{NO}_{3}{ }^{-}$versus $\mathrm{DO}$, note $\mathrm{x}$ axis is $\log$ scaled $\mathbf{B} \delta^{15} \mathrm{~N}_{\text {in }} \mathrm{NO}_{3}{ }^{-}$versus DOC

directly from the terrace aquifer with no riparian area upgradient. The remaining two spring sites (Star and Spr555) have only a few meters of riparian area upgradient, which does not appear to be sufficient to support notable denitrification (Table 1). Abundant DO in shallow terrace aquifers limiting denitrification outside of riparian corridors stands in contrast to systems with deeper aquifers with longer residence times that facilitate variable subsurface electron donor depletion of DO and complicate prediction of aquifer $\mathrm{NO}_{3}{ }^{-}$lag times (Kolbe et al. 2019; Vautier et al. 2021). When sampled upgradient of riparian influence, the consistent $\delta^{15} \mathrm{~N}_{\mathrm{NO}_{3}}, \delta^{18} \mathrm{O}_{\mathrm{NO}_{3}}$, and $\mathrm{NO}_{3}{ }^{-}$concentration of Moccasin terrace groundwater provides a chemical starting point to which stream chemistry can be compared to infer denitrification process within the riparian corridor.

\section{Isotopic signals of denitrification}

Both the clearest presence and the clearest absence of denitrification signals were observed in groundwater, with differentiation apparently related to abundance of DO and DOC (Fig. 2; Table 1). Four of the seven groundwater sites exhibited no primary signals of denitrification (Table 1; Indian, Star, Grove, Spr555). Isotopic influence of denitrification in the two nonriparian wells (M1 and Headwaters) was not evident, 
with mixed signals from $\delta^{18} \mathrm{O}: \delta^{15} \mathrm{~N}, \delta^{15} \mathrm{~N}: \ln \left[\mathrm{NO}_{3}{ }^{-}\right]$, $\delta^{15} \mathrm{~N}: \ln [\mathrm{DO}]$, and $\delta^{15} \mathrm{~N}: \mathrm{DOC}$ relationships (Table 1 ; Fig. S3). Across all groundwaters, DO explains $73 \%$ of the observed variation in $\delta^{15} \mathrm{~N}_{\mathrm{NO} 3}\left(\mathrm{R}^{2}=0.73\right.$, linear regression of $\delta^{15} \mathrm{~N}_{\mathrm{NO} 3}$ vs $\ln [\mathrm{DO}]$ ), consistent with the idea that regardless of DOC abundance, DO needs to be low before substantial denitrification is likely to occur (Fig. 3). The only riparian groundwater site where DO concentrations were consistently low (Pioneer), displayed clear $\delta^{18} \mathrm{O}: \delta^{15} \mathrm{~N}$ and $\delta^{15} \mathrm{~N}: \ln \left[\mathrm{NO}_{3}{ }^{-}\right]$ signals of denitrification along with a $\delta^{15} \mathrm{~N}$ :DOC corroborating signal. This clear signal of denitrification at one riparian groundwater site, representing a "hotspot," juxtaposed to four riparian groundwater sites lacking any evidence of denitrification, underscores the high variability in riparian denitrification rates and extent, similar to findings in other studies (Hedin et al. 1998; McClain et al. 2003; Vidon and Hill 2006). To be clear, this distinction reflects our site selection process, which targeted inclusion of springs draining the terrace aquifer at the base of steep embankments without upgradient riparian vegetation, in order to distinguish denitrification in the terrace aquifer versus riparian groundwater.

Patterns in stream water chemistry and isotopic composition reveal a stronger signal of denitrification in the riparian corridor of Louse Creek than in that for Porter Creek. Unlike fallow soil waters and groundwaters, the strong denitrification signals for Louse Creek (Table 1) could be confounded by algal uptake in the water column, which may also favor the light isotope (Denk et al. 2017). However, the persistence of higher $\delta^{15} \mathrm{~N}_{\mathrm{NO}_{3}}$ values in Louse Creek relative to groundwater through the winter of 2013-2014 when algal growth was likely minimal, supports the hypothesis that denitrification is an important driver of riparian corridor and instream $\mathrm{NO}_{3}{ }^{-}$loss. The lack of correlation between $\delta^{15} \mathrm{~N}_{\mathrm{NO}_{3}}$ and DO measured in the water column may reflect that stream channel denitrification occurs under anoxic conditions found in the hyporheic zone, benthic sediment, and/or suspended sediment (Harvey et al. 2013; Gomez-Velez et al. 2015; Reisinger et al. 2016; Wells et al. 2019). In general, both the lack of correlation between $\delta^{15} \mathrm{~N}_{\mathrm{NO}_{3}}$ and DO measured in the water column and the persistent $\delta^{15} \mathrm{~N}$ :DOC relationship may simply indicate that riparian denitrification precedes inflows to Louse Creek, where reoxygenation occurs (Table 1, Fig. 3). Porter Creek water indicates no isotopic evidence of denitrification, when assessed independently. However, leveraging the consistent chemical signature of high DO groundwater in the terrace aquifer, when results from a spring flowing into Porter Creek (Grove Spring) are grouped with those from Porter Creek, stronger $\delta^{18} \mathrm{O}: \delta^{15} \mathrm{~N}, \delta^{15} \mathrm{~N}: \ln \left[\mathrm{NO}_{3}{ }^{-}\right]$, and $\delta^{15} \mathrm{~N}$ :DOC denitrification signals emerge (Table 1). This pattern from groundwater to stream water supports the inference from mass balance analysis (Sigler et al. 2018), that riparian corridor $\mathrm{NO}_{3}{ }^{-}$losses for both Louse (50\%) and Porter (15\%) creeks are at least partially attributable to riparian denitrification.

Denitrification signals across the full set of lysimeter-sampled soil waters are weak $\left(\delta^{15} \mathrm{~N}: \ln \left[\mathrm{NO}_{3}{ }^{-}\right]\right.$ $\left.\mathrm{R}^{2}=0.04, \delta^{15} \mathrm{~N}: \ln \left[\mathrm{NO}_{3}{ }^{-}\right] \mathrm{R}^{2}=0.13\right)$, but evidence of denitrification is stronger $\left(\mathrm{R}^{2}=0.50,0.32\right)$ in deep soils during fallow periods (Table 1). In simplest terms, evidence of denitrification in soil during fallow periods is consistent with findings by Sigler et al. (2020) that soil moisture is higher during fallow periods than in cropped years. Higher water content in the presence of soil organic matter increases the chances of regions with low DO, which would facilitate denitrification (DeKlein and VanLogtestijn 1996; Smith et al. 1997). The concomitant increases in soil $\mathrm{NO}_{3}{ }^{-}$concentrations during the fallow year, observed both in lysimeter samples (Sigler et al. 2018) and soil profile inventories (John et al. 2017; Sigler et al. 2020), indicate that ammonification of SON and subsequent nitrification is out-pacing denitrification and leaching losses during this period. Nitrate with the highest $\delta^{15} \mathrm{~N}_{\mathrm{NO}_{3}}$ and $\delta^{18} \mathrm{O}_{\mathrm{NO}_{3}}$ values occurs early (March-April) in the fallow year when $\mathrm{NO}_{3}{ }^{-}$concentrations are low, and isotopic values decrease over the fallow year. These patterns are consistent with denitrification favored by anoxic conditions in more saturated soils associated with snowmelt early in the season, followed by nitrification favored by more oxic conditions and moderate soil water content during the warmer and drier season. Decreases in $\delta^{15} \mathrm{~N}_{\mathrm{NO}_{3}}$ values with increases in $\mathrm{NO}_{3}{ }^{-}$concentration during summer suggest nitrification following ammonification of SON, supplying $\mathrm{NO}_{3}{ }^{-}$with a $\delta^{15} \mathrm{~N}_{\mathrm{NO}_{3}}$ value of $\sim+5 \%$. Decreases in $\delta^{18} \mathrm{O}_{\mathrm{NO}_{3}}$ values with nitrification may reflect incorporation of oxygen from water having relatively low $\delta^{18} \mathrm{O}$ values, consistent with water stored in soil from snowmelt (Fig. S1) and incorporated by nitrification through the summer fallow period. 
Estimating fallow soil denitrification rates

The Monte Carlo ensemble of realizations of the isotopic composition of $\mathrm{NO}_{3}{ }^{-}$produced a median annual denitrification rate of $26 \mathrm{~kg} \mathrm{~N} / \mathrm{ha} / \mathrm{yr}$ and an interquartile range of $12-56 \mathrm{~kg} \mathrm{~N} / \mathrm{ha} / \mathrm{yr}$ (Fig. 4C), values well within the range of denitrification estimates across ecosystem types reported for annual timeframes ( 0 to $239 \mathrm{~kg} \mathrm{~N} / \mathrm{ha} / \mathrm{yr}$; Phillips 2008). The mode of the ensemble was $7 \mathrm{~kg} \mathrm{~N} / \mathrm{ha} / \mathrm{yr}$, which is approximately half of values summarized for agricultural soils from a global synthesis $(14 \mathrm{~kg} \mathrm{~N} / \mathrm{ha} / \mathrm{yr}$; Seitzinger et al. 2006) and the mean value from a literature review (13 kg N/ha/yr; Barton et al. 1999). The mode of the ensemble is less than the 25th quartile value (12 kg N/ha/yr), and is reported here as a conservatively low estimate. A denitrification rate of $7 \mathrm{~kg} \mathrm{~N} /$ ha/yr would suggest $17 \%$ of the $\mathrm{NO}_{3}{ }^{-}$entering the soil pool from SON during the fallow period is lost

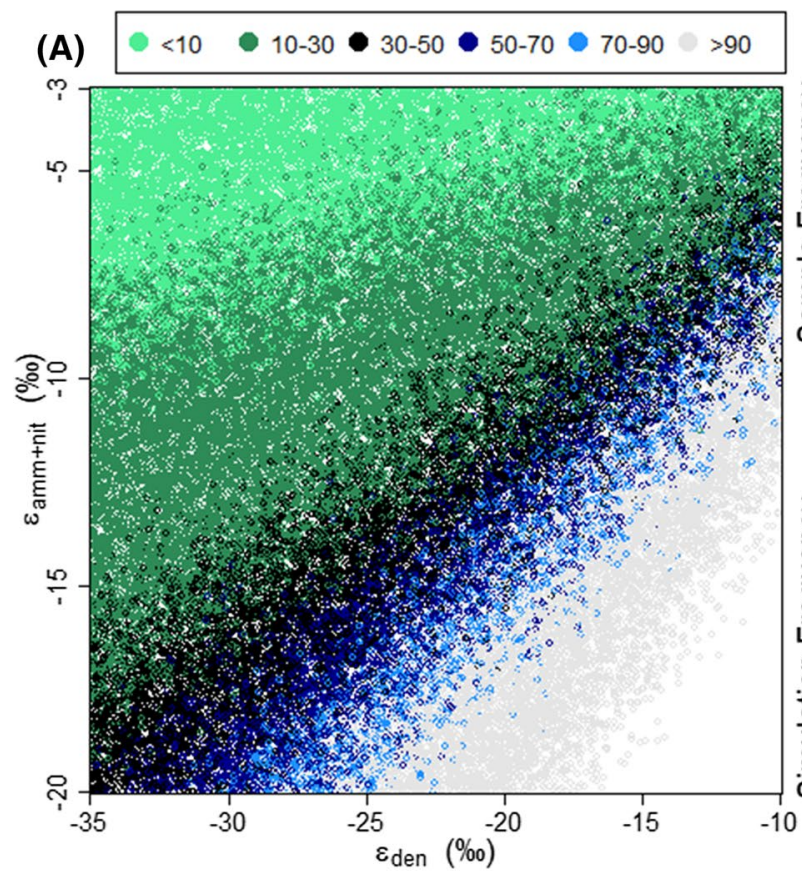

Fig. 4 Simulation based estimates of annual soil denitrification rates during fallow. A Monte Carlo simulation (50,000 realizations) results for the annual denitrification rate during the fallow year $\left(N_{\mathrm{den}, T}\right)$ based on Eqs. 1 and 2 and assumptions described in the methods section. Each point represents results from one realization with annual soil denitrification rate depicted by color according to the legend and isotope effect values for ammonification + nitrification $\left(\varepsilon_{\text {amm+nit }}\right)$ and denitrification $\left(\varepsilon_{\mathrm{den}}\right)$ correspond to the $\mathrm{Y}$ and $\mathrm{X}$ axes. The bottom to denitrification. We anticipate that overall warm season denitrification rates are higher during summer fallow years when soils are wetter, relative to summers with crops present when soils are drier (DeKlein and VanLogtestijn 1996). Implications for patterns in the $\mathrm{N}_{2} \mathrm{O}$ component of denitrification surrounding summer fallow are less clear due to limited research. Nitrous oxide emissions are commonly quantified as a fraction of $\mathrm{N}$ fertilizer applied, an approach focused on cropped years, but with recent attention to the role of non-growing season fallow periods (Shang et al. 2020). Some research has found higher $\mathrm{N}_{2} \mathrm{O}$ emissions from crop relative to fallow (Verma et al. 2006). Other studies have found $\mathrm{N}_{2} \mathrm{O}$ fluxes associated with precipitation events were higher than those associated with fertilizer application (Barton et al. 2008; Wilson et al. 2015). Further work is needed to quantify denitrification rates during summer fallow relative to cropped years, and to illuminate drivers

(B)

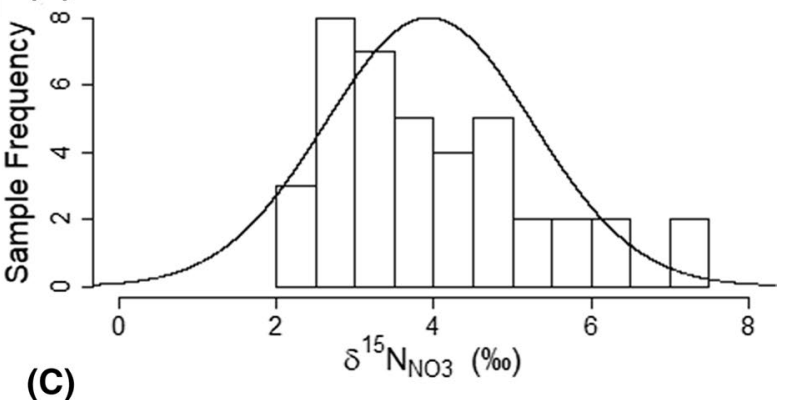

(C)

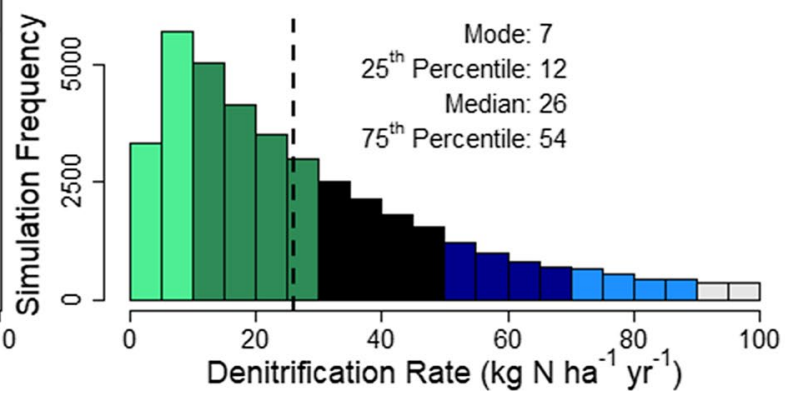

right portion of the plot represents parameter space where simulations produced $r_{\text {den }}$ values greater than 1, values which are not meaningful according to model assumptions. B Frequency of $\delta^{15} \mathrm{~N}$ values observed in soil lysimeter samples $\left(\delta^{15} \mathrm{~N}_{\mathrm{NO}_{3}}\right.$; $n=38$ ), with a line depicting the normal distribution fit to the data that was used to generate $\delta^{15} \mathrm{~N}_{\mathrm{NO}_{3}}$ values for the Monte Carlo simulation. C Frequency of annual denitrification rates simulated with the Monte Carlo analysis (same data in panel A) 
of $\mathrm{N}_{2} \mathrm{O}$ emissions associated with both denitrification and nitrification under summer fallow conditions to inform mitigation strategies (Barton et al. 2013; Vazquez et al. 2019).

Our upland soil denitrification estimates on the order of $7-26 \mathrm{~kg} \mathrm{~N} / \mathrm{ha} / \mathrm{yr}$ suggest that large gross losses of $\mathrm{NO}_{3}{ }^{-}$to denitrification may occur during summer fallow periods, even when they are masked by net $\mathrm{NO}_{3}^{-}$accumulation from mineralization of SON. As a result, these losses may be obscured or interpreted as leaching loss in mass balance approaches where denitrification is not directly quantified (Bouwman et al. 2013; John et al. 2017). A $26 \mathrm{~kg} \mathrm{~N} / \mathrm{ha} / \mathrm{yr}$ loss of $\mathrm{NO}_{3}{ }^{-}$during fallow years might be expected to result in a measurable loss of SON over time. However, given that uncertainty in SON values is approximately $310 \mathrm{~kg} / \mathrm{ha}(10 \%$ of $3,100 \mathrm{~kg} /$ ha; see Supplemental Information), losses of less than $30 \mathrm{~kg} \mathrm{~N} / \mathrm{ha} / \mathrm{yr}$ would be difficult to detect without decades of data. Long-term SON trends are not available for our study area, but under a similar climate in Montana, soil organic carbon decreased over time in systems with summer fallow periods in rotation (Engle et al. 2017), a result standing in contrast to increasing SON observed in wetter climates where summer fallowing is not practiced (Sebilo et al. 2013; Van Meter et al. 2016). If the soil denitrification rate is $26 \mathrm{~kg} \mathrm{~N} / \mathrm{ha} / \mathrm{yr}$, this loss is $1.5-2.5$ times higher than estimated leaching rates (11-18 kg/ha/yr; Sigler et al. 2018 ) and at least $25 \%$ of common fertilizer rates in the watershed (60-100 kg/ha/yr; John et al. 2017). Loss of $\mathrm{N}_{\mathrm{r}}$ from soils represents a loss of stored fertility, and SON derived losses will ultimately be offset by increased fertilizer application, likely exacerbating fertilizer $\mathrm{N}_{\mathrm{r}}$ use inefficiency, increasing $\mathrm{N}_{2} \mathrm{O}$ emissions and further degrading downstream water quality.

Our denitrification rate estimates based on $\delta^{15} \mathrm{~N}_{\mathrm{NO}_{3}}$ and first order kinetics are sensitive to the magnitude of the assumed isotopic fractionation effects. This source of uncertainty illustrated by the Monte Carlo analysis (Fig. 4) is seldom assessed or reported in work based on the same isotopic principles (Lutz et al. 2020), but may be important to appropriate confidence in research conclusions. More work is needed to better constrain the isotopic effects associated with ammonification plus nitrification and denitrification as well as additional possible loss pathways of intermediate reactants to refine these rate estimates. The steady state approach to application of nitrification and denitrification isotopic effects (Eq. 2) to determine the net composition of the $\mathrm{NO}_{3}{ }^{-}$pool is a simplified approach for estimating the range of possible denitrification rates suggested by observed $\delta^{15} \mathrm{~N}_{\mathrm{NO}_{3}}$ values. Future modeling considering more complicated temporal patterns of nitrification and denitrification is necessary to enhance understanding of net denitrification in agricultural soils. Additional enhancement of the soil denitrification model could also be accomplished at this site by incorporating $\delta^{18} \mathrm{O}_{\mathrm{NO}_{3}}$ as a second tracer, a step that would require refined characterization of $\delta^{18} \mathrm{O}$ in rain and snow along with storage and transport dynamics through soil.

Implications for landscape $\mathrm{N}$ budgets and future work

The isotopic composition of $\mathrm{NO}_{3}{ }^{-}$at these sites suggests that denitrification is occurring in both riparian corridors (which include soils, shallow subsurface flow and side channels, ponds and impoundments) and cultivated soils of our study area, a finding widely supported in the literature (Hedin et al. 1998; Bouwman et al. 2013; Billen et al. 2020). Riparian areas had the strongest isotopic signals of denitrification, with some riparian groundwater hotspots suggesting near complete $\mathrm{NO}_{3}{ }^{-}$removal. While riparian denitrification is well documented with observations and modeling because it confers water quality benefits for streams (Zarnetske et al. 2012; Oldham et al. 2013), these $\mathrm{N}_{\mathrm{r}}$ losses must be evaluated in a broader landscape context and in light of associated greenhouse gas $\left(\mathrm{N}_{2} \mathrm{O}\right)$ emissions. Here, when riparian denitrification is normalized to the catchment area $(1-5 \mathrm{~kg} \mathrm{~N} /$ ha/yr; Sigler et al. 2018), these losses are small relative to potential direct losses (7-26 kg N/ha/yr) from more spatially extensive cultivated soils (Fig. 5). Further, the $\mathrm{NO}_{3}{ }^{-}$undergoing denitrification in riparian corridors is primarily sourced from upgradient cultivated soils, highlighting the central role of cultivated soils in overall $\mathrm{N}_{\mathrm{r}}$ budgets for cultivated landscapes. These findings support both calls to bolster strategic management of riparian corridors and wetlands (Cheng et al. 2020) and to allocate more attention to $\mathrm{N}$ management in the soils of uplands and headwater catchments (Pinay and Haycock 2019). Loss of $\mathrm{N}_{\mathrm{r}}$ from cultivated soils via denitrification and leaching not only limits agricultural productivity but also has 


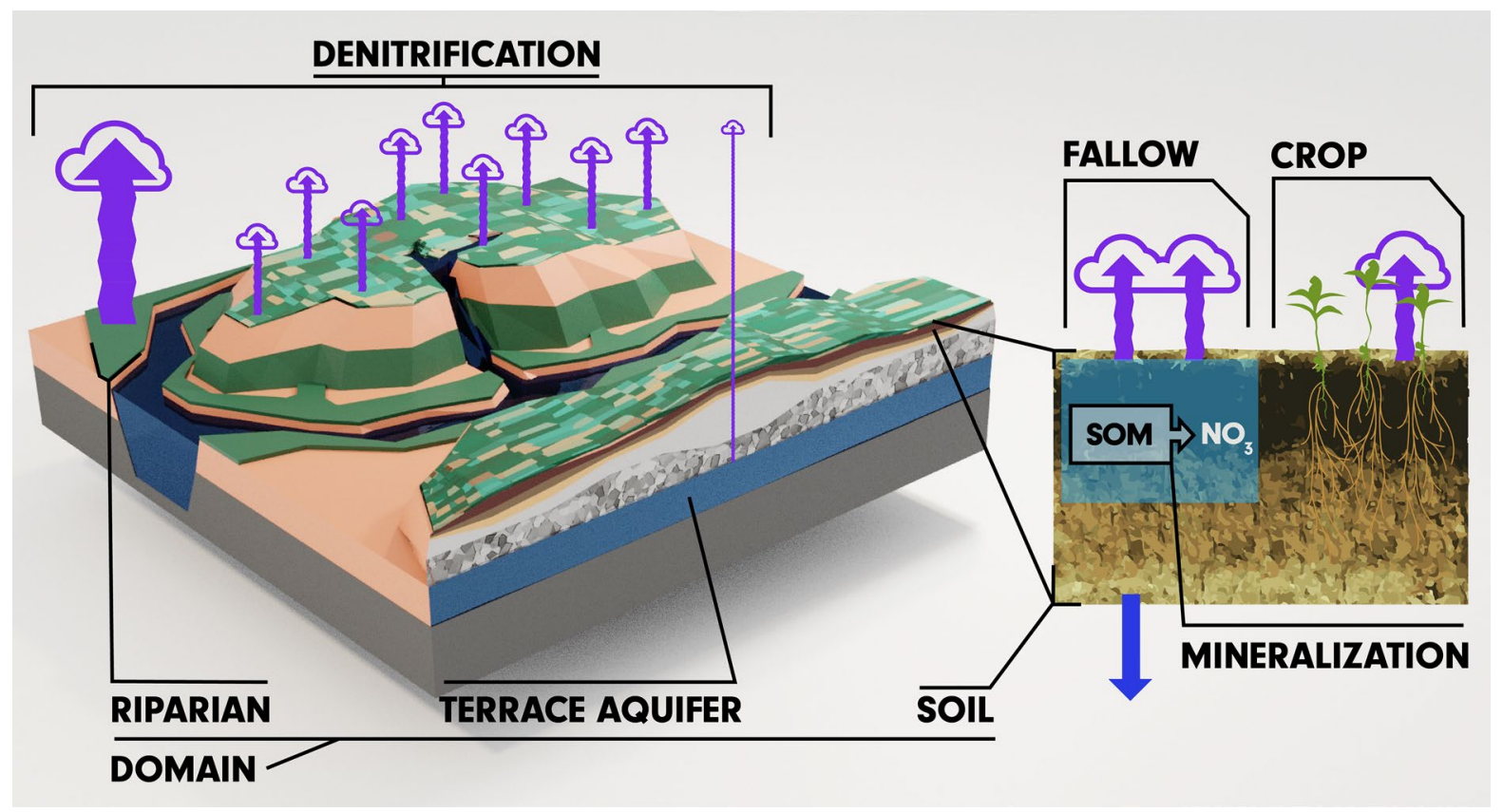

Fig. 5 Landscape denitrification domains. Size of upward facing arrows represent magnitude of denitrification $\mathrm{N}$ flux for the different portions of the landscape. Denitrification within oxy-

contributed to a ten-fold increase in $\mathrm{N}_{2} \mathrm{O}$ emissions from croplands since the 1860s (Stevens and Laughlin 1998; Tian et al. 2019; Billen et al. 2020). Results from our work suggest that fallow periods play a disproportionately important role in $\mathrm{N}_{\mathrm{r}}$ loss from cropland soils both directly to denitrification, and to leaching (Sigler et al. 2020) of $\mathrm{NO}_{3}{ }^{-}$that is subject to denitrification down gradient. More generally, this work shows that spatial connection, as well as transport and reactivity dynamics, shape the isotopic patterns that we observe (Abbott et al. 2016). Ultimately our work supports the view that protecting thin riparian buffers is often insufficient to restore water quality and biogeochemical function in managed aquatic ecosystems (Pinay and Hancock 2019).

Evidence of concurrent nitrification and denitrification during fallow periods is consistent with previous work indicating that the two processes can be tightly coupled in space and time in soils (Seitzinger et al. 2006). Decades of work has suggested that nitrification occurs near oxygenated macropores and that oxygen and $\mathrm{NO}_{3}{ }^{-}$diffuse into adjacent micropores, where microbial respiration uses up oxygen, leading to anoxia and denitrification (Parkin 1987; Parkin genated terrace aquifers is minimal. Large magnitude $\mathrm{N}$ losses in riparian areas are localized, while lower magnitude losses in upland soils are spatially extensive

and Berry 1999; Schlüter et al. 2018). Soils in semiarid regions with crops present are typically dry with only episodic periods of soil water content above field capacity, but summer fallowing dramatically increases the duration and spatial extent of high soil water content (Sigler et al. 2020). For future work, we pose the hypothesis that overall soil water is increased during fallow periods, but that interspersed faster drying zones adjacent to macropores or coarse texture anomalies create complex networks of oxic and anoxic zones in close proximity, with high potential for coupled nitrification and denitrification. The patterns of oxic/anoxic zones are likely controlled by climate, management, parent material, and soil structure (Ewing et al. 2006; Sigler et al. 2020). Based on this hypothesis, we posit that fallow periods may create the perfect storm for high rates of nitrification, which produces $\mathrm{NO}_{3}{ }^{-}$at high risk of loss to leaching or denitrification in cultivated soil. As global cultivated land spends ca. $50 \%$ of time in a fallow condition, additional work is needed to quantify denitrification rates during fallow periods and the extent to which these processes contribute to $\mathrm{N}_{2} \mathrm{O}$ emissions from food production systems (Clark et al. 2020), which 
are necessary to meet Paris Agreement goals to slow global temperature increase.

Acknowledgements The authors would like to thank cooperating farmers, local partners, and the MSU Central Agricultural Research Center (CARC) and lead field technician Simon Fordyce. Thank you to two anonymous reviewers for insightful comments that improved the manuscript, and to Marco Huot for work on Fig. 5 with material from Jennifer Rogers. This work was funded by the United States Department of Agriculture, National Institute of Food and Agriculture [grant number 2011-51130-31121, 2011] and USDA NIFA grant number 2016-67026-25067. Additional funding was provided by MSU Extension, Montana Fertilizer Advisory Committee, the Montana Agricultural Experiment Station, MSU Vice President of Research, MSU College of Agriculture, and the Montana Institute on Ecosystems. This work was supported in part by the National Science Foundation EPSCoR Track 1 award to the Consortium for Research on Environmental Water Systems, Cooperative Agreement OIA-1757351, as well as NSF EPSCoR Track 1 award numbers OIA-1443108 and EPS-1101342.

Funding National Institute of Food and Agriculture, 201151130-31121, S. A. Ewing, 2011, S. A. Ewing, 2016-6702625067, S. A. Ewing, Montana State University Extension, Montana Fertilizer Advisory Committee, Montana Agricultural Experiment Station, Montana State University Vice President of Research, Montana State University College of Agriculture, Montana Institute on Ecosystems, NSF EPSCoR, OIA-1757351, S. A. Ewing, OIA-1443108, S. A. Ewing, EPS110134, S. A. Ewing.

Data availability Data and code available as a resource on Hydroshare (Sigler et al. 2022).

\section{Declarations}

Conflict of interest The authors declare that they have no conflicts of interest.

Open Access This article is licensed under a Creative Commons Attribution 4.0 International License, which permits use, sharing, adaptation, distribution and reproduction in any medium or format, as long as you give appropriate credit to the original author(s) and the source, provide a link to the Creative Commons licence, and indicate if changes were made. The images or other third party material in this article are included in the article's Creative Commons licence, unless indicated otherwise in a credit line to the material. If material is not included in the article's Creative Commons licence and your intended use is not permitted by statutory regulation or exceeds the permitted use, you will need to obtain permission directly from the copyright holder. To view a copy of this licence, visit http://creativecommons.org/licenses/by/4.0/.

\section{References}

Abbott BW, Baranov V, Mendoza-Lera C, Nikolakopoulou M, Harjung A, Kolbe T, Balasubramanian MN, Vaessen TN, Ciocca F, Campeau A, Wallin MB, Romeijn P, Antonelli M, Goncalves J, Datry T, Laverman AM, de Dreuzy J-R, Hannah DM, Krause S, Oldham C, Pinay G (2016) Using multi-tracer inference to move beyond single-catchment ecohydrology. Earth-Sci Rev 160:19-42. https://doi.org/ 10.1016/j.earscirev.2016.06.014

Ascott MJ, Gooddy DC, Wang L, Stuart ME, Lewis MA, Ward RS, Binley AM (2017) Global patterns of nitrate storage in the vadose zone. Nat Commun 8:1416. https://doi.org/ 10.1038/s41467-017-01321-w

Baer DS, Paul JB, Gupta JB, O'Keefe A (2002) Sensitive absorption measurements in the near-infrared region using off-axis integrated-cavity-output spectroscopy. Appl Phys B-Lasers Opt 75:261-265. https://doi.org/10.1007/ s00340-002-0971-z

Barton L, McLay CDA, Schipper LA, Smith CT (1999) Annual denitrification rates in agricultural and forest soils: a review. Aust J Soil Res 37:1073-1093. https://doi.org/10. 1071/SR99009

Barton L, Kiese R, Gatter D, Butterbach-Bahl K, Buck R, Hinz C, Murphy DV (2008) Nitrous oxide emissions from a cropped soil in a semi-arid climate. Glob Change Biol 14:177-192. https://doi.org/10.1111/j.1365-2486.2007. 01474.X

Barton L, Gleeson DB, Maccarone LD, Zuniga LP, Murphy DV (2013) Is liming soil a strategy for mitigating nitrous oxide emissions from semi-arid soils? Soil Biol Biochem 62:28-35. https://doi.org/10.1016/j.soilbio.2013.02.014

Becker M, Asch F, Maskey SL, Pande KR, Shah SC, Shrestha $S$ (2007) Effects of transition season management on soil $\mathrm{N}$ dynamics and system $\mathrm{N}$ balances in rice-wheat rotations of Nepal. Field Crops Res 103:98-108. https://doi.org/10. 1016/j.fcr.2007.05.002

Benettin P, Volkmann THM, von Freyberg J, Frentress J, Penna D, Dawson TE, Kirchner J (2018) Effects of climatic seasonality on the isotopic composition of evaporating soil waters. Hydrol Earth Syst Sci 22:2881-2890. https://doi. org/10.5194/hess-22-2881-2018

Billen G, Garnier J, Grossel A, Thieu V, Théry S, Hénault C (2020) Modeling indirect $\mathrm{N} 2 \mathrm{O}$ emissions along the $\mathrm{N}$ cascade from cropland soils to rivers. Biogeochemistry. https://doi.org/10.1007/s10533-020-00654-X

Bochet O, Bethencourt L, Dufresne A, Farasin J, Pedrot M, Labasque T, Chatton E, Lavenant N, Petton C, Abbott BW, Aquilina L, Le Borgne T (2020) Iron-oxidizer hotspots formed by intermittent oxic-anoxic fluid mixing in fractured rocks. Nat Geosci 13:149. https://doi.org/10. 1038/s41561-019-0509-1

Boshers DS, Granger J, Tobias CR, Bohlke J, Smith RL (2019) Constraining the Oxygen Isotopic Composition of Nitrate Produced by Nitrification. Environ Sci Technol 53:12061216. https://doi.org/10.1021/acs.est.8b03386

Bouwman AF, Beusen AHW, Griffioen J, Van Groenigen JW, Hefting MM, Oenema O, Van Puijenbroek PJTM, Seitzinger S, Slomp CP, Stehfest E (2013) Global trends and uncertainties in terrestrial denitrification 
and N2O emissions. Philos. Trans. r. Soc. B Biol. Sci. 368(1621):20130112. https://doi.org/10.1098/rstb.2013. 0112

Buchwald C, Casciotti KL (2010) Oxygen isotopic fractionation and exchange during bacterial nitrite oxidation. Limnol Oceanogr 55:1064-1074. https://doi.org/10.4319/lo. 2010.55.3.1064

Campbell CA, Selles F, Zentner RP, De Jong R, Lemke R, Hamel C (2006) Nitrate leaching in the semiarid prairie: effect of cropping frequency, crop type, and fertilizer after 37 years. Can J Soil Sci 86:701-710

Caraco NF, Cole JJ (1999) Human impact on nitrate export: an analysis using major world rivers. Ambio 28:167-170

Casciotti KL, Sigman DM, Hastings MG, Böhlke JK, Hilkert A (2002) Measurement of the oxygen isotopic composition of nitrate in seawater and freshwater using the denitrifier method. Anal Chem 74:4905-4912. https://doi.org/10. 1021/ac020113w

Casciotti KL, McIlvin M, Buchwald C (2010) Oxygen isotopic exchange and fractionation during bacterial ammonia oxidation. Limnol Oceanogr 55:753-762. https:// doi.org/10.4319/1o.2009.55.2.0753

Cheng FY, Van Meter KJ, Byrnes DK, Basu NB (2020) Maximizing US nitrate removal through wetland protection and restoration. Nature 588:625-630. https://doi.org/10. 1038/s41586-020-03042-5

Clark MA, Domingo NGG, Colgan K, Thakrar SK, Tilman D, Lynch J, Azevedo IL, Hill JD (2020) Global food system emissions could preclude achieving the $1.5^{\circ}$ and $2^{\circ} \mathrm{C}$ climate change targets. Science $370: 705-708$. https://doi.org/10.1126/science.aba7357

Committee on Twenty-First Century Systems Agriculture (2010) Toward sustainable agricultural systems in the 21st century. National Academies Press, Washington, DC.

Davis MP, Groh TA, Jaynes DB, Parkin TB, Isenhart TM (2019) Nitrous oxide emissions from saturated riparian buffers: are we trading a water quality problem for an air quality problem? J Environ Qual 48:261-269. https://doi. org/10.2134/jeq2018.03.0127

DeKlein CaM, VanLogtestijn RSP (1996) Denitrification in grassland soils in The Netherlands in relation to irrigation, $\mathrm{N}$-application rate, soil water content and soil temperature. Soil Biol Biochem 28:231-237. https://doi.org/10. 1016/0038-0717(95)00131-X

Del Grosso SJ, Parton WJ, Mosier AR, Ojima DS, Kulmala AE, Phongpan S (2000) General model for N2O and N-2 gas emissions from soils due to dentrification. Glob Biogeochem Cycles 14:1045-1060. https://doi.org/10.1029/ 1999GB001225

Denk TRA, Mohn J, Decock C, Lewicka-Szczebak D, Harris E, Butterbach-Bahl K, Kiese R, Wolf B (2017) The nitrogen cycle: a review of isotope effects and isotope modeling approaches. Soil Biol Biochem 105:121-137. https:// doi.org/10.1016/j.soilbio.2016.11.015

Ehrhardt S, Kumar R, Fleckenstein JH, Attinger S, Musolff A (2019) Trajectories of nitrate input and output in three nested catchments along a land use gradient. Hydrol Earth Syst Sci 23:3503-3524. https://doi.org/10.5194/ hess-23-3503-2019
Engel RE, Miller PR, McConkey BG, Wallander R (2017) Soil organic carbon changes to increasing cropping intensity and no-till in a semiarid climate. Soil Sci Soc Am J 81:404-413. https://doi.org/10.2136/sssaj2016.06.0194

Erisman JW, Sutton MA, Galloway J, Klimont Z, Winiwarter W (2008) How a century of ammonia synthesis changed the world. Nat Geosci 1:636-639. https://doi.org/10.1038/ ngeo325

Ewing SA, Sutter B, Owen J, Nishiizumi K, Sharp W, Cliff SS, Perry K, Dietrich W, McKay CP, Amundson R (2006) A threshold in soil formation at Earth's arid-hyperarid transition. Geochim Cosmochim Acta 70:5293-5322. https:// doi.org/10.1016/j.gca.2006.08.020

Ewing SA, Stricker C, Sigler WA (2022) Summary of nitrogen isotope ratios $(\mathrm{d} 15 \mathrm{~N})$ in cultivated and uncultivated soil profiles of the Judith River Watershed, HydroShare. https://doi.org/10.4211/hs.918ea9194af04d66aea6e5aea $7 \mathrm{~b} 6 \mathrm{cc} 24$

Firestone M, Davidson E (1989) Microbiological basis of NO and $\mathrm{N} 2 \mathrm{O}$ production and consumption in soil. John Wiley \& Sons Ltd, Chichester

Foley JA, Ramankutty N, Brauman KA, Cassidy ES, Gerber JS, Johnston M, Mueller ND, O'Connell C, Ray DK, West PC, Balzer C, Bennett EM, Carpenter SR, Hill J, Monfreda C, Polasky S, Rockstrom J, Sheehan J, Siebert S, Tilman D, Zaks DPM (2011) Solutions for a cultivated planet. Nature 478:337-342. https://doi.org/10.1038/natur e10452

Fry B (2006) Stable isotope ecology, 1st edn. Springer, New York, NY

Galloway JN, Aber JD, Erisman JW, Seitzinger SP, Howarth RW, Cowling EB, Cosby BJ (2003) The nitrogen cascade. Bioscience 53:341-356. https://doi.org/10.1641/00063568(2003)053[0341:TNC]2.0.CO;2

Gomez-Velez JD, Harvey J, Cardenas MB, Kiel B (2015) Denitrification in the Mississippi River network controlled by flow through river bedforms. Nat Geosci 8:941-U75. https://doi.org/10.1038/NGEO2567

Goolsby DA, Battaglin WA, Lawrence GB, Artz RS, Aulenbach BT, Hooper RP, Keeney DR, Stensland GJ (1999) Flux and sources of nutrients in the Mississippi-Atchafalaya River basin: topic 3 report for the integrated assessment on hypoxia in the Gulf of Mexico.

Granger J, Wankel SD (2016) Isotopic overprinting of nitrification on denitrification as a ubiquitous and unifying feature of environmental nitrogen cycling. Proc Natl Acad Sci USA 113:E6391-E6400. https://doi.org/10.1073/pnas. 1601383113

Granger J, Sigman DM, Lehmann MF, Tortell PD (2008) Nitrogen and oxygen isotope fractionation during dissimilatory nitrate reduction by denitrifying bacteria. Limnol Oceanogr 53:2533-2545. https://doi.org/10.4319/lo.2008. 53.6.2533

Groffman PM, Altabet MA, Bohlke JK, Butterbach-Bahl K, David MB, Firestone MK, Giblin AE, Kana TM, Nielsen LP, Voytek MA (2006) Methods for measuring denitrification: diverse approaches to a difficult problem. Ecol Appl 16:2091-2122. https://doi.org/10.1890/1051-0761(2006) 016[2091:MFMDDA]2.0.CO;2

Hall SJ, Weintraub SR, Bowling DR (2016) Scale-dependent linkages between nitrate isotopes and denitrification in 
surface soils: implications for isotope measurements and models. Oecologia 181:1221-1231. https://doi.org/10. 1007/s00442-016-3626-1

Harvey JW, Böhlke JK, Voytek MA, Scott D, Tobias CR (2013) Hyporheic zone denitrification: controls on effective reaction depth and contribution to whole-stream mass balance. Water Resour Res 49:6298-6316. https://doi.org/ 10.1002/wrcr.20492

Hedin LO, von Fischer JC, Ostrom NE, Kennedy BP, Brown MG, Robertson GP (1998) Thermodynamic constraints on nitrogen transformations and other biogeochemical processes at soil-stream interfaces. Ecology 79:684-703

Houlton BZ, Sigman DM, Hedin LO (2006) Isotopic evidence for large gaseous nitrogen losses from tropical rainforests. Proc Natl Acad Sci 103:8745-8750. https://doi.org/10. 1073/pnas.0510185103

John AA, Jones CA, Ewing SA, Sigler WA, Bekkerman A, Miller PR (2017) Fallow replacement and alternative nitrogen management for reducing nitrate leaching in a semiarid region. Nutr Cycl Agroecosyst 108:279-296. https://doi.org/10.1007/s10705-017-9855-9

Kendall C, McDonnell JJ (1998) Isotope tracers in catchment hydrology. Elsevier, Amsterdam, New York

Kendall C, Elliott EM, Wankel SD (2007) Tracing anthropogenic inputs of nitrogen to ecosystems. Wiley-Blackwell, Malden

Kolbe T, de Dreuzy J-R, Abbott BW, Aquilina L, Babey T, Green CT, Fleckenstein JH, Labasque T, Laverman AM, Marcais J, Peiffer S, Thomas Z, Pinay G (2019) Stratification of reactivity determines nitrate removal in groundwater. Proc Natl Acad Sci USA 116:2494-2499. https://doi. org/10.1073/pnas.1816892116

Liu C, Wang K, Meng S, Zheng X, Zhou Z, Han S, Chen D, Yang Z (2011) Effects of irrigation, fertilization and crop straw management on nitrous oxide and nitric oxide emissions from a wheat-maize rotation field in northern China. Agric Ecosyst Environ 140:226-233. https://doi.org/10. 1016/j.agee.2010.12.009

Lutz SR, Trauth N, Musolff A, Breukelen BMV, Knöller K, Fleckenstein JH (2020) How important is denitrification in riparian zones? Combining end-member mixing and isotope modeling to quantify nitrate removal from riparian groundwater. Water Resour Res 56:e2019WR025528. https://doi.org/10.1029/2019WR025528

Mariotti A, Germon J, Hubert P, Kaiser P, Letolle R, Tardieux A, Tardieux P (1981) Experimental-determination of nitrogen kinetic isotope fractionation-some principles-illustration for the denitrification and nitrification processes. Plant Soil 62:413-430. https://doi.org/10.1007/ BF02374138

McClain ME, Boyer EW, Dent CL, Gergel SE, Grimm NB, Groffman PM, Hart SC, Harvey JW, Johnston CA, Mayorga E, McDowell WH, Pinay G (2003) Biogeochemical hot spots and hot moments at the interface of terrestrial and aquatic ecosystems. Ecosystems 6:301-312. https:// doi.org/10.1007/s10021-003-0161-9

Nielsen DC, Unger PW, Miller PR (2005) Efficient water use in dryland cropping systems in the Great Plains. Agron J 97:364-372. https://doi.org/10.2134/agronj2005.0364

Oldham CE, Farrow DE, Peiffer S (2013) A generalized Damkohler number for classifying material processing in hydrological systems. Hydrol Earth Syst Sci 17:11331148. https://doi.org/10.5194/hess-17-1133-2013

Parkin T (1987) Soil microsites as a source of denitrification variability. Soil Sci Soc Am J 51:1194-1199. https://doi. org/10.2136/sssaj1987.03615995005100050019x

Parkin TB, Berry EC (1999) Microbial nitrogen transformations in earthworm burrows. Soil Biol Biochem 31:17651771. https://doi.org/10.1016/S0038-0717(99)00085-1

Phillips RL (2008) Denitrification in cropping systems at subzero soil temperatures. A review. Agron Sustain Dev 28:87-93. https://doi.org/10.1051/agro:2007045

Pinay G, Haycock NE (2019) Diffuse nitrogen pollution control: moving from riparian zone to headwater catchment approach-a tribute to the influence of professor Geoff Petts. River Res Appl 35:1203-1211. https://doi.org/10. 1002/rra.3488

Probert ME, Dimes JP, Keating BA, Dalal RC, Strong WM (1998) APSIM's water and nitrogen modules and simulation of the dynamics of water and nitrogen in fallow systems. Agric Syst 56:1-28. https://doi.org/10.1016/S0308521X(97)00028-0

Puckett LJ, Tesoriero AJ, Dubrovsky NM (2011) Nitrogen contamination of surficial aquifers-a growing legacy $\dagger$. Environ Sci Technol 45:839-844. https://doi.org/10.1021/ es 1038358

Reisinger AJ, Tank JL, Hoellein TJ, Hall RO (2016) Sediment, water column, and open-channel denitrification in rivers measured using membrane-inlet mass spectrometry. J Geophys Res Biogeosci 121:1258-1274. https://doi.org/ 10.1002/2015JG003261

Rockstrom J, Steffen W, Noone K, Persson A, Chapin FS, Lambin E, Lenton TM, Scheffer M, Folke C, Schellnhuber HJ, Nykvist B, de Wit CA, Hughes T, van der Leeuw S, Rodhe H, Sorlin S, Snyder PK, Costanza R, Svedin U, Falkenmark M, Karlberg L, Corell RW, Fabry VJ, Hansen J, Walker B, Liverman D, Richardson K, Crutzen P, Foley J (2009) Planetary boundaries: exploring the safe operating space for humanity. Ecol Soc 14:32

Rolston DE, Sharpley AN, Toy DW, Broadbent FE (1982) Field measurement of denitrification: III. rates during irrigation cycles 1. Soil Sci Soc Am J 46:289-296. https:// doi.org/10.2136/sssaj1982.03615995004600020015x

Safriel U, Adeel Z (2005) Dryland systems. In: Hassan R, Scholes R, Ash N (eds) Ecosystems and human wellbeing: current state and trends, vol 1. Island Press, Washington, DC

Sander BO, Samson M, Buresh RJ (2014) Methane and nitrous oxide emissions from flooded rice fields as affected by water and straw management between rice crops. Geoderma 235:355-362. https://doi.org/10.1016/j.geoderma. 2014.07.020

Scheer C, Wassmann R, Klenzler K, Lbragimov N, Eschanov R (2008) Nitrous oxide emissions from fertilized irrigated cotton (Gossypium hirsutum L.) in the Aral Sea Basin, Uzbekistan: influence of nitrogen applications and irrigation practices. Soil Biol Biochem 40:290-301. https://doi. org/10.1016/j.soilbio.2007.08.007

Schlüter S, Henjes S, Zawallich J, Bergaust L, Horn M, Ippisch O, Vogel H-J, Dörsch P (2018) Denitrification in soil aggregate analogues-effect of aggregate size and oxygen 
diffusion. Front Environ Sci 6:17. https://doi.org/10.3389/ fenvs.2018.00017

Schlüter S, Zawallich J, Vogel H-J, Dörsch P (2019) Physical constraints for respiration in microbial hotspots in soil and their importance for denitrification. Biogeosciences 16:3665-3678. https://doi.org/10.5194/bg-16-3665-2019

Sebilo M, Mayer B, Nicolardot B, Pinay G, Mariotti A (2013) Long-term fate of nitrate fertilizer in agricultural soils. Proc Natl Acad Sci 110:18185-18189. https://doi.org/10. 1073/pnas.1305372110

Seitzinger S, Harrison JA, Bohlke JK, Bouwman AF, Lowrance R, Peterson B, Tobias C, Van Drecht G (2006) Denitrification across landscapes and waterscapes: a synthesis. Ecol Appl 16:2064-2090. https://doi.org/10.1890/10510761(2006)016[2064:DALAWA]2.0.CO;2

Shang Z, Abdalla M, Kuhnert M, Albanito F, Zhou F, Xia L, Smith P (2020) Measurement of N2O emissions over the whole year is necessary for estimating reliable emission factors. Environ Pollut 259:113864. https://doi.org/10. 1016/j.envpol.2019.113864

Siebert S, Doll P, Hoogeveen J, Faures JM, Frenken K, Feick S (2005) Development and validation of the global map of irrigation areas. Hydrol Earth Syst Sci 9:535-547. https:// doi.org/10.5194/hess-9-535-2005

Siebert S, Portmann FT, Döll P, Siebert S, Portmann FT, Döll P (2010) Global patterns of cropland use intensity. Remote Sens 2:1625-1643. https://doi.org/10.3390/rs2071625

Sigler WA, Ewing SA, Jones CA, Payn RA, Brookshire ENJ, Klassen JK, Jackson-Smith D, Weissmann GS (2018) Connections among soil, ground, and surface water chemistries characterize nitrogen loss from an agricultural landscape in the upper Missouri River Basin. J Hydrol 556:247-261. https://doi.org/10.1016/j.jhydrol.2017.10. 018

Sigler WA, Ewing SA, Jones CA, Payn RA, Miller P, Maneta $M$ (2020) Water and nitrate loss from dryland agricultural soils is controlled by management, soils, and weather. Agric Ecosyst Environ 304:107158. https://doi.org/10. 1016/j.agee.2020.107158

Sigler WA, Ewing SA, Wankel SD, Leuthold S, Payn R, Jones CA (2022) Isotopic signals in an agricultural watershed suggest denitrification is locally intensive in riparian areas but extensive in upland soils - data and code, HydroShare. https://doi.org/10.4211/hs.f9f36a39190e4cc6a7cdc0cd0 cc9bdd6

Sigman DM, Casciotti KL, Andreani M, Barford C, Galanter M, Böhlke JK (2001) A bacterial method for the nitrogen isotopic analysis of nitrate in seawater and freshwater. Anal Chem 73:4145-4153

Smith VH (2003) Eutrophication of freshwater and coastal marine ecosystems - a global problem. Environ Sci Pollut Res 10:126-139. https://doi.org/10.1065/espr2002.12.142

Smith KA, McTaggart IP, Tsuruta $\mathrm{H}$ (1997) Emissions of $\mathrm{N}_{2} \mathrm{O}$ and $\mathrm{NO}$ associated with nitrogen fertilization in intensive agriculture, and the potential for mitigation. Soil Use Manag 13:296-304. https://doi.org/10.1111/j.1475-2743. 1997.tb00601.x

Sparks DL (2003) Environmental soil chemistry, 2nd edn. Academic Press, Boston

Stevens RJ, Laughlin RJ (1998) Measurement of nitrous oxide and di-nitrogen emissions from agricultural soils. Nutr
Cycl Agroecosystems 52:131-139. https://doi.org/10. 1023/A:1009715807023

Tesoriero AJ, Puckett LJ (2011) O-2 reduction and denitrification rates in shallow aquifers. Water Resour Res 47:W12522. https://doi.org/10.1029/2011WR010471

Tesoriero AJ, Duff JH, Saad DA, Spahr NE, Wolock DM (2013) Vulnerability of streams to legacy nitrate sources. Environ Sci Technol 47:3623-3629. https://doi.org/10. 1021/es305026x

Tian H, Yang J, Xu R, Lu C, Canadell JG, Davidson EA, Jackson RB, Arneth A, Chang J, Ciais P, Gerber S, Ito A, Joos F, Lienert S, Messina P, Olin S, Pan S, Peng C, Saikawa E, Thompson RL, Vuichard N, Winiwarter W, Zaehle S, Zhang B (2019) Global soil nitrous oxide emissions since the preindustrial era estimated by an ensemble of terrestrial biosphere models: magnitude, attribution, and uncertainty. Glob Change Biol 25:640-659. https://doi.org/10. $1111 / \mathrm{gcb} .14514$

USDA (2014) National agricultural statistics service cropland data layer. Available from http://nassgeodata.gmu.edu/ CropScape/. Accessed Sept 8, 2016.

Van Meter KJ, Basu NB, Veenstra JJ, Burras CL (2016) The nitrogen legacy: emerging evidence of nitrogen accumulation in anthropogenic landscapes. Environ Res Lett 11:035014. https://doi.org/10.1088/1748-9326/11/3/ 035014

Vautier C, Kolbe T, Babey T, Marcais J, Abbott BW, Laverman AM, Thomas Z, Aquilina L, Pinay G, de Dreuzy J-R (2021) What do we need to predict groundwater nitrate recovery trajectories? Sci Total Environ 788:147661. https://doi.org/10.1016/j.scitotenv.2021.147661

Vazquez E, Benito M, Navas M, Espejo R, Diaz-Pines E, Teutscherova N (2019) The interactive effect of no-tillage and liming on gross $\mathrm{N}$ transformation rates during the summer fallow in an acid Mediterranean soil. Soil Tillage Res 194:104297. https://doi.org/10.1016/j.still.2019. 104297

Verma A, Tyagi L, Yadav S, Singh SN (2006) Temporal changes in $\mathrm{N}_{2} \mathrm{O}$ efflux from cropped and fallow agricultural fields. Agric Ecosyst Environ 116:209-215. https:// doi.org/10.1016/j.agee.2006.02.005

Vidon PG, Hill AR (2006) A landscape-based approach to estimate riparian hydrological and nitrate removal functions. J Am Water Resour Assoc 42:1099-1112. https://doi.org/ 10.1111/j.1752-1688.2006.tb04516.x

Vitousek PM, Aber JD, Howarth RW, Likens GE, Matson PA, Schindler DW, Schlesinger WH, Tilman DG (1997) Human alteration of the global nitrogen cycle: sources and consequences. Ecol Appl 7:737-750. https://doi.org/10. 1890/1051-0761(1997)007[0737:HAOTGN]2.0.CO;2

Wells NS, Clough TJ, Johnson-Beebout SE, Buresh RJ (2014) Land management between crops affects soil inorganic nitrogen balance in a tropical rice system. Nutr $\mathrm{Cycl}$ Agroecosyst 100:315-332. https://doi.org/10.1007/ s10705-014-9644-7

Wells NS, Clough TJ, Johnson-Beebout SE, Elberling B, Baisden WT (2019) Effects of denitrification and transport on the isotopic composition of nitrate (delta O-18, delta $\mathrm{N}-15$ ) in freshwater systems. Sci Total Environ 651:22282234. https://doi.org/10.1016/j.scitotenv.2018.10.065 
Wilson TM, McGowen B, Mullock J, Arnall DB, Warren JG (2015) Nitrous oxide emissions from continuous winter wheat in the southern great plains. Agron J 107:18781884. https://doi.org/10.2134/agronj15.0096

Zarnetske JP, Haggerty R, Wondzell SM, Bokil VA, GonzalezPinzon R (2012) Coupled transport and reaction kinetics control the nitrate source-sink function of hyporheic zones. Water Resour Res 48:W11508. https://doi.org/10. 1029/2012WR011894
Publisher's Note Springer Nature remains neutral with regard to jurisdictional claims in published maps and institutional affiliations. 